\title{
Tipologija pridevniške vezljivosti
}

\author{
Andreja Žele
}

IZVLEČEK: Prispevek predstavlja /ne/izglagolske pridevnike $z$ vidi$k$ a njihovih vezljivostnih lastnosti v povedku in s tem hkrati tudi njihovo večjo ali manjšo stopnjo povedkovniškosti. Vezljivostno merilo torej lahko tudi med pridevniškimi besedami izloči prave povedkovnike (z nekaj tipičnimi pridevniškimi lastnostmi, zato jih lahko poimenujemo kot pridevniške povedkovnike). V vsakem primeru je vezljivost tudi pri pridevniških iztočnicah pomembno pomenskoskladenjsko merilo pri izbiri razlagalnega gradiva.

ABSTRACT: The article presents (non-)verbal adjectives, focusing on their valency properties within the predicate and at the same time on a higher or lower degree of their "predicativeness". The criterion of valency thus makes it possible to distinguish between true predicatives (on the grounds of some typical adjectival features they may be called adjectival predicatives) and other adjectives. Nevertheless, valency is an important semantic-syntactic criterion for choosing explanatory material even for adjectival entries.

Pri pridevniški vezljivosti so obravnavani pridevniki v povedkovi rabi, eni s popolnoma ohranjenim prvotnim pomenjem in drugi z metonimičnimi ali celo metaforičnimi pomeni glede na prvotno leksemsko pomenje posameznih pridevnikov. Govorimo lahko o zloženem povedku in o povedkovi vezljivosti. Vse to je t. i. desna vezljivost, medtem ko je ujemalna (v spolu, sklonu, številu) leva vezljivost povedkovodoločilnega pridevnika obravnavana zgolj kot stavkotvorni pogoj.

Obseg prispevka opravičujem s tem, da je njegova vrednost ravno v pregledno-problemski obravnavi celotnega gradiva - le zaokroženi fond primerov iz Slovarja slovenskega knjižnega jezika namreč omogoča dejansko predstavitev uporabe pridevnikov v (zloženem) povedku in možno vezljivostno delitev pridevnikov.

Obravnavani so predvsem neizglagolski pridevniki, ker pri izglagolskih pridevnikih - popridevljenih deležnikih stanja glede na glagolsko vezljivost ni bistvenih odstopanj (z vidika določanja (stopnje) pridevniškosti so pomembni deležniki stanja iz dovršnih neprehodnih glagolov). Neizglagolski pridevniki so izčrpneje obdelani ravno zaradi neglagolskih stanjsko-lastnostnih pomenskih sestavin, ki lahko uvajajo vezljivost. Oboji (neizglagolski in izglagolski) imajo v povedkovodoločilni 

ljivost. Pri izglagolskih pridevnikih je vezljivost posledica izhodiščnega glagolskega pomena, pri neizglagolskih pridevnikih pa je vezljivost posledica dinamičnega pomena pomensko sorodnih glagolov. Prvotna povedkovodoločilna vloga navadno $\mathrm{z}$ brisanjem oz. izgubo določenih kategorij (npr. pri samostalniku in pridevniku spola in sklona, pri glagolu časa in naklona) ali s pridobivanjem določenih kategorij (npr. spreganja) in izoblikovanjem nove kombinacije pomensko-slovničnih kategorij omogoča obstoj povedkovnika kot samostojne besedne vrste.' Tudi za povedkovnik je torej bistven specifični skladenjski pomen, ki opredeljuje določeno dejansko/prisotno lastnostno stanje ${ }^{2}-\mathrm{z}$ vidika nove besedne vrste lahko govorimo o t. i. 'leksikalni osamosvojitvi' (Mluvnice češtiny 1986: 76); besedna oblika (pregibna/nepregibna, kratka/dolga ipd.) ni relevantna ${ }^{3}$ oz. povedkovnik za specializirane skladenjske pomene pretežno nima specializiranih oblik. Povedkovnik je torej označen s položajskostjo - ne nanaša se na osebke ali predmete oz. jih ne označuje ali pojasnjuje. Čeprav je tipični povedkovniški stavčni položaj ob brezosebnih okoliščinah, je z vidika leve vezljivosti relevantna delitev povedkovnikov na t. i. osebne in neosebne. ${ }^{4}$ Skladenjskopomenski dokaz za povedkovnik pa je smiselna nadomestitev z glagolsko obliko. ${ }^{5}$ Tipični skladenjski pomen stanjskosti in posledične lastnostnosti povedkovnikov potrjujejo tudi drugotne izpeljave v samostalnike na ost. $^{6}$

1 A. Vidovič Muha (2000b: 31) govori o »spremembi kategorialnih lastnosti /.../, ki povzroči prehod ene besedne vrste v drugo /.../ ». Ista avtorica (gl. A. Vidovič Muha 2000b: 125) npr. za leksem človek ugotavlja, da v povedkovodoločilni vlogi s pomenom 'human, človeški' lahko vedno tvori lastnostne stavke - iz tega posledično potrdi upravičenost kategorialne pomenskosestavinske oznake povedkovnik za tovrstne lekseme tudi $\mathrm{v}$ slovarjih. Osnovne splošne značilnosti povedkovnikov, ne samo pridevniških, so bile predstavljene tudi v zadnji številki Jezikoslovnih zapiskov (Žele 2000: 57-58).

2 Po A. V. Isačenku (1954: 255) t. i. »kačestvennoe sostojanie«, pri Čehih (Mluvnice češtiny 1986: 195) pa t. i. »kategorie stavu«.

${ }^{3}$ Kot določevalno merilo za povedkovnike A. V. Isačenko (1954: 250) navaja tudi skladenjsko vlogo povedkovega prilastka, ki je z izražanjem 'spremstvenega stanja' pomenskoskladenjsko soroden povedkovemu določilu. To dokazuje s pretvorbenim razmerjem med Sin se je vrnil bolan - Sin se je vrnil. Bil je bolan ipd.

${ }^{4}$ Glede na to, ali povedkovniki razlikujejo osebo ali ne, jih J. Toporišič $(1982: 116 ; 2000$ : 596-597) deli na osebne (sem/si/je tiho/v skrbeh) in neosebne ( je treba / je mraz) povedkovnike; z vidika desne vezljivosti pa na prehodne (biti v skrbeh za kaj, Treba nam je miru) in neprehodne (biti tiho, biti mraz) povedkovnike.

${ }^{5}$ Skladenjskopomensko posebne so redke deležniške oblike, vzlično rabljene v zvezah tipa Živel predsednik, Pozdravljen prijatelj, slovarsko (po SSKJ) je prva označena kot medmet, druga pa kot deležniško podgeslo pri glagolski iztočnici pozdraviti. Vendar tu bi težko govorili o povedkovniku - prej gre za izvenjezikovnosistemsko govorno uresničitev, ki vključuje še druge izvenjezikovne okoliščine, ki jo hkrati omogočajo. Tovrstno rabo v jeziku pa omogoča nadpovedna besedilna skladnja, v okviru povedi pa ni samozadostna.

6 Po A. V. Isačenku (1960: 567-568) pa so samostalniške tvorjenke na -ost dodatna potrditev prevlade lastnosti $\mathrm{v}$ povedkovniški rabi. 


\section{Vezljivost kot pomensko- in strukturnoskladenjska kategorija pridevnikov}

Vezljivostni (skladenjskopomenski) vidik je lahko eno izmed vodilnih meril za določanje povedkovniškosti oz. za določanje povedkovih skladenjskih pomenov. Stopnja skladenjskopomenske utrjenosti v stavčnem položaju za vezjo je hkrati pokazatelj stopnje povedkovniškosti določenih pridevniških besed.

$Z$ vidika leve vezljivosti je skupna slovnična oz. strukturnoskladenjska kategorija glagolov in pridevnikov ujemalnost (prim. Morfológia slovenského jazyka 1966: 209).

Za potrditev pomensko- in strukturnoskladenjske pridevniške vezljivosti pa je pomemben tudi primerjalnoslovanski vidik. ${ }^{7}$

Pri slovenski pridevniški vezljivosti velja izpostaviti Dajnkovo in Metelkovo slovnico, obe pisani po zgledu slovnice J. Dobrovskega. Obe v okviru strukturnoskladenjske (sklonske) vezljivosti naštejeta tudi vezljive pridevniške besede. Dajnko in Metelko opozarjata, kako/ne/izglagolski pridevniški pomeni tudi usmerjajo udeležence oz. določajo rabo sklonov. Metelko (1825: 226) še posebej, tudi s skladenjskopomenskega vidika, obravnava rabo pridevnikov v povedku. V slovensko pisanih slovnicah A. Breznik opozarja na pridevniško vezljivost tako s strukturnoskladenjskega kot s pomenskoskladenjskega vidika (1916: 248-251; 1921: 218-221; 1924: 217-219; 1934: 224-226).

Nova slovenska skladnja (J. Toporišič 1982) v okviru obravnave pridevniške besedne zveze našteva pridevniške besede, ki vežejo rodilniška, dajalniška in predložna določila. S predložnimi določili se izpostavijo tudi vezavni predložni morfemi ob pridevniških besedah. Povedkovi pomožnopomenski (naklonski) pridevniki so obdelani v okviru glagolske zveze z glagolom (NSS: 101-102). Pomožnopomenski pridevniški deležniki stanja v povedku uvajajo obvezno pridevniško desno vezljivost. Vezljivost pridevniških besed je omenjana še pri upovedovalnih naklonskih (hotenjske, možnostne, gotovostne, čustvenostne in zanikanja) določitvah (NSS: 226-295).

7 Zgodaj je tudi na pridevniško intenco opozoril V. V. Vinogradov (1947: 402-405). Posebej, z zgledi, obravnava vezljivost pridevnikov vesel, zmožen, dolžen, neprijeten, namenjen, prepričan, očiten in ugotavlja skladenjskopomenski prevzem povedkovih lastnosti. V sorodnih slovanskih jezikih, npr. v hrvaščini (Katičić 1986: 125-127) so našteti pridevniki, ki v povedku lahko smiselno nadomeščajo glagolske oblike: - z rodilnikom: pun, sit, gladan, žedan, željan, dostojan, vrijedan; - z dajalnikom: vješt, ravan, drag, mio; - z orodnikom: zadovoljan, izobilan, bogat, siromašan; v slovaščini (Morfológia slovenského jazyka 1966: 209-210) se govori o intenci pridevnika: - z rodilnikom: željen, zmožen, udeležen, poln, sit, lačen, zaveden, Ine/vreden; - s predložnim tožilnikom: lakomen na premoženje, dovzeten za vraže, izveden za vse; - z dajalnikom: zvest, potreben, znan, primeren, oddan, poslušen, naklonjen, soroden, podoben, tuj, oddaljen, pristopen; $-\mathrm{z}$ orodnikom: zaseden $z$; - primernik in presežnik sta zaradi primerjave vedno vezavna: najlepši med vrstniki ipd. 
Pregled zgledov pridevniške vezljivosti po nekaj skladenjsko odločilnejših slovnicah. Primeri za mestnik in orodnik izkazujejo prostomorfemski predlog:

$-$

Dajnko (1824: 277-285):

$z$ rodilnikom: doveden, gladen, lačen, nevreden, potreben, nepotreben, poln, sit, žeden, želčen, vreden, veden;

0

Metelko (1825: 238-240):

$\mathrm{z}$ dajalnikom: podoben, povolen, priličen, pokoren, primeren, poročen.

$\mathrm{z}$ rodilnikom: skrben, maren, marljiv, boječ, plašen, poln, sit, pijan, vajen, prazen, potreben, lačen, žejen, pozabljiv, pomljiv, zvest, željan, lakomen, varčen, vesel, deležen, vreden, kriv; s predložnim rodilnikom: primerniki tipa večji od, mlajši od; $\mathrm{z}$ dajalnikom: enak, podoben, koristen, lasten, ljub, priljuden, priličen, priležen, pokoren, podložen, podveržen, postrežen, prijeten, dopadljiv, zvest, mil, milostljiv, škodljiv, nevoščljiv, dober, znan, gorek; s predložnim tožilnikom: jezen na, zaljubljen v;

Breznik (1934: 224-226): $\mathrm{z}$ orodnikom: bogat $\mathrm{z}$, reven $\mathrm{z}$. z rodilnikom: željen, lakomen, skrben, potreben, poln, vreden, kriv, deležen; $\mathrm{z}$ dajalnikom: koristen, škodljiv, primeren, prikladen, enak, pristojen, vdan, všeč, blag, mil, dober, drag, ugoden, potreben;

is - z orodnikom: bogat $\mathrm{z}$;

- $\quad$ s predložnim tožilnikom: lakomen na, mrtev na.

\section{Toporišič:}

(NSS: 57-61):

- $\quad$ z rodilnikom: lačen, sit; dolžen, željan, vesel, boječ, sramujoče se, želeči se, držeči se, veseleči se, varujoči se, čakajoči, stradajoči, dolžeči;

- $\quad$ z dajalnikom: enak, naklonjen, podoben, koristen, lasten, ljub, priljuden, priličen, primerjen, pokoren, podložen, podvržen, postrežen, prijeten, dopadljiv, zvest, mil, milostljiv, škodljiv, tečen, nevoščljiv, dober, znan, gorek, vdan, obljubljen/obljubujoč;

- $\quad$ s predložnim tožilnikom: jezen na, naslonjen na, nor na, bolan na;

- $\quad$ z mestnikom: misleč o, pridelan na;

- $\quad$ z orodnikom: posut s, najlepša med;

(SS 2000: 327-328): z rodilnikom: poln, sit, pijan, vajen, potreben, lačen; žejen, svest si, željen, 
vesel, deležen, vreden, kriv, bogat, prijazen do;

- $\quad$ z dajalnikom: enak, podoben, koristen, lasten, primeren, pokoren, podložen, podvržen, prijeten, dopadljiv, uslužen, zvest, milostljiv, škodljiv, nevoščljiv, dober, znan, gorak, težeč k;

- $\quad$ s tožilnikom: potreben za, požrešen na, nor na, jezen na, zaljubljen v, zavzet za, vpleten v;

- $\quad$ z mestnikom: pohlepen po, hrepeneč po;

- $\quad$ orodnikom: bogat $z$, varčen $z$, reven $z$, začuden nad.

\section{Besedotvorje in vezljivost}

$\mathrm{Z}$ besedotvornega vidika pridevniški sklopi z nikalnico ne- in pridevniške sestavljenke s pre- ('preveč') nakazujejo izhodiščno podstavo v povedku. Poleg tega pridevniške sestavljenke s predponskim obrazilom odpirajo desno vezljivost.

1) Pri sklopih z nikalnico ne- je pomenski poudarek na zanikanju stanja/ lastnosti $\mathrm{v}$ povedku - sklopi so s povedkom v pretvorbenem razmerju. Nekateri odkrivajo široko pomensko polje, nemogoč, neumen, nepomemben, od čiste nikalnice do drugih pomenskih premikov oz. prenosov, ki so slovarsko navadno označeni z ekspr(esivno):

nemogoč 'ki ni mogoč': Tu je dvom nemogoč, V tistih krajih je življenje skoraj nemogoče;

nemogoč (ekspr.) 'ki zaradi svojega vedenja, ravnanja vzbuja nenaklonjenost, odpor': Ta človek je nemogoč;

nemogoč (ekspr., s širokim pomenskim obsegom) 'slab, neprimeren': Ima nemogoč plašč, Njegovi prevodi so nemogoči;

neumen 'ki ne ravna v skladu z razumom, pametjo': Mlad je še in neumen; neumen 'ki ni sposoben hitro dojemati, prodorno misliti': Preveč je neumen; neumen (ekspr.) 'neprimeren, neustrezen': Te pentlje na obleki so prav neumne;

nepomemben (ekspr.) 'ki ni pomemben': Pri tem delu se jim je zdel nepotreben in nepomemben;

nepomemben (knjiž., ekspr.) 'majhen, neznaten': Količina se jim je zdela nepomembna.

Zgornje sklope z nikalnico v pomensko-skladenjskih podstavah pa glede na tipe slovarskih pomenskih razlag, ki izhajajo iz leksemskega pomenja, lahko skupinimo:

- pretvorbeno razmerje z zanikanim istokorenskim pridevnikom v povedku: nelogičen 'ki ni logičen': Njegova želja je nelogična; neopažen 'ki ni opažen': Neopažen je odšel od doma; neugoden 'ki ni ugoden': Čas je bil zelo neugoden; 
- z zanikanim povedkom v podstavi:

nesmiseln 'ki nima možnosti za uspeh': Njegovo prizadevanje je nesmiselno; nerazumljiv (ekspr.) 'ki se ne da odobravati': Njegova izjava je res nerazumljiva; nevzdržen (nav. ekspr.) 's katerim se ne da soglašati, strinjati': Njegovo stališče je nevzdržno;

nespameten (ekspr.) 'ki ne ravna v skladu s pametjo, razumom': $\mathrm{S}$ tem se ne bo strinjal, saj ni nespameten;

\section{- z opisno ali besedno sinonimijo:}

nedotaknjen 'ki je ostal v nespremenjenem položaju ali obliki': Postelja je ostala nedotaknjena;

nepotreben (ekspr.) 'ki je nastal brez pravega vzroka ali podlage': Te napake so čisto nepotrebne;

netakten (ekspr.) 'ki mu manjka takta, olike': Fant je nekoliko netakten;

neučakan 'ki težko čaka, pričakuje': Ne bodi tako neučakan; neverjeten (ekspr.) 'ki vzbuja začudenje, presenečenje': Ta človek je neverjeten; nevšečen 'ki povzroča neprijetnosti, težave': Že ves dan je nevšečen; nepobiten (knjiž.) 'neovrgljiv, neizpodbiten': Dokaz je nepobiten; nevzdržen (ekspr.) 'neprimeren, slab': Njegov pložaj je nevzdržen.

2) Prislovni pomen predponskega obrazila pre- = 'preveč' s primerjalnorazmernim odnosom med udeleženci odpira možnost neobvezne vezljivosti; največkrat $\mathrm{s}$ predložnotožilniškim $\left(\mathrm{T}_{\mathrm{za}}\right)$ udeležencem. Našteto bo samo nekaj primerov $\mathrm{z}$ različnimi pomenskimi razlagami:

predebela 'ki je preveč debela': Ta knjiga/ženska je predebela; predebela (ekspr.)

'ki je zelo pretirana, neverjetna': Novica je predebela; prepičel (nav ekspr.) 'ki je preveč pičel': Hrana je prepičla'; presamoten (ekspr.) 'preveč samoten': Človek je presamoten; preuranjen (publ.) 'prezgodnji': Revolucija je preuranjena; preuranjen 'prenagljen, nepremišljen': Odločitev je preuranjena.

\section{Slovarske oznake in pojasnila v okviru povedkovodoločilne vloge pridevniških besed}

Najpogostejši oznaki pri pridevnikih v povedkovi rabi, ki opozarjata na prednostno povedkovodoločilno vlogo pridevniških besed, sta knjiž(no) in ekspr(esivno ${ }^{8}$. Širitev osnovnega pomenja oz. širša skladenjskopomenska raba ima pogosto tudi dvojo oznako knjiž(no) ekspr(esivno). Na pomenske premike opozarjajo tudi kronološke oznake star(insko) in zastar(elo), s slednjo so označene besede, ki so že izpadle iz leksikalnega sistema knjižnega jezika.

V okvir oznake knjiž(no) je potrebno vključiti tako prvotno leksikalnoformalno oz. inherentno knjižnost kot drugotno besedilno oz. adherentno knjižnost. ${ }^{9}$

${ }^{8}$ V zvezi z razmerjem pomen : ekspresija je v Uvodu prve knjige SSKJ (1970: XXI) pomembna opomba, da je ekpresivnost večkrat povezana $\mathrm{z}$ delnim pomenskim premikom.

${ }_{9}$ Pri nas je knjižna leksika z vzporedno predstavitvijo slovanskih teoretičnih smernic ana- 
Obe vrsti knjižnosti sta upoštevani pri povedkovodoločilnih vlogah pridevnikov, tako da opredeljujeta povedkovodoločilne lastnosti teh pridevnikov. Pri povedkovodoločilni rabi pridevnikov gre za prevlado t. i. adherentne knjižne ekspresije.

Pri prenesenih pomenih pa metaforični pomeni izstopajo iz izhodiščnih pomenov in njihovih pomenskih sestavin. $Z$ metaforičnimi pomeni so nanovo dodane razločevalne pomenske sestavine (RPS), ki se opomenijo na skladenjskofunkcijski ravni v novi denotat - povedkovnik. Lahko pa ostanejo samo na skladenjskofunkcijski (konotativni) ravni in se ne leksikalizirajo. ${ }^{10}$ Nove (metaforične) razločevalne pomenske sestavine oz. lastnosti se posplošijo na motivirajoče/izhodiščne pomene in tako omogočijo nastanek novih metaforičnih pomenov. Npr. nečloveške lastnosti se posplošijo na človeka: Bolnikje ves trhel, Ta človek je votel, in obratno: Vreme je spodobno/prijazno. Primerjalno so zanimivi še metaforični premiki kot $\breve{Z} e$ čez nekaj dni je postal domač, Predsednikje preprost in ljudski, Zlasti nižja inteligenca je bila ljudska. Na pomensko širjenje izhodiščnega pomena opozarjajo tudi prostomorfemski pridevniki, npr. Ves divji je nanj, Ves mrtev je na klobase, Je volčji na denar, Ta človek je odprt za vsakogar, Vsi so sladki z njim ipd.

Oslabljeni in široki slovarski pomeni so skladenjskopomenski namig na kar navadno povedkovo rabo.

Med slovničnimi in pomenskimi kategorijami, ki poudarjajo povedkovniškost, so: nesklonskost ( $=>$ neujemalnost in netipična prilastkovna raba), naklonskost in skladenjska pomenskost ( $=>$ drugotni, oslabljeni ali široki pomeni pridevnikov).

\section{Vezljivost povedkovodoločilnih (neizglagolskih) pridevnikov}

Pri neizglagolskih pridevnikih, ki so potencialno desno vezljivi, gre predvsem za stanjske pridevnike - povedkovnike, so podskupina kakovostnih pridevnikov, ki izražajo stanje." Vendar to stanje, nasproti izglagolskim pridevnikom, ni posledica glagolskega dejanja. ${ }^{12}$ Pri povedkovniških pridevnikih je v okviru povedkovodoločilne rabe prvotni (razmerno)stanjski pomen in drugotni lastnostni pomen $^{13}$, ki izpostavlja nosilca, pri katerem stanjska lastnost ostaja ali pa se razmerno

lizirana v članku A. Vidovič Muhe Kategorizacija in stilna opredelitev ozko knjižne leksike (1972: 35-52).

${ }^{10} \mathrm{O}$ metaforah v leksikalni semantiki gl. v članku A. Vidovič Muha Čas v besedi - Tipologija leksikalne večpomenskosti (2000a: 85-109).

" S skladenjskopomenskega vidika je zanje značilna okrnjenost skladenjske vloge, tj. vezanost na povedkovo rabo (Vidovič Muha 1978: 262).

${ }^{12}$ Sicer pa o izvornosti pridevnikov oz. predvsem o »izgubi prvotnega participialnega pomena « in o "pridobitvi pridevniškega« piše A. Bajec (1952: 29, 36, 42, 48). Ugotavlja, da »/so/ deležniki često postali pridevniki in to je jezik tudi na zunaj izrazil s tem, da jim je dodal ekspletivni formant $-\partial n \ll$.

${ }^{13}$ A. Vidovič Muha (1978: 259-260) ugotavlja, da lastnostne pridevnike pomensko povezuje dejstvo, da poimenujejo lastnosti relativne ocene, tj. vrednotijo. Za duševnolastnostne in telesnolastnostne ugotavlja možnost desne pomenske usmerjenosti, izražene $\mathrm{z}$ desnimi določili, za atmosferske pridevnike pa možnost sinonimnosti v predikativu stanja. 
razširi še na druge potencialne udeležence. Glede na pomensko usmerjenost tovrstnih pridevnikov oz. glede na njihovo skladenjsko pomenskost ločujemo absolutno ali relativno vezljive in nevezljive pridevnike. ${ }^{14}$

Osnovne lastnosti tovrstnih neizglagolskih pridevnikov so:

- Manjša pomenska odvisnost od samostalnika - nasproti prilastkovi rabi, ki pomensko opredeljuje določen samostalnik, povedkovodoločilna raba določeni osebi/ stvari samo prisoja lastnost ali stanje (gre za neimanentno/nenotranjo stanjsko lastnost s pretvorbeno možnostjo v glagolskem dejanju). ${ }^{15} \mathrm{Z}$ vidika osebkovega samostalnika gre torej za prisojevano priložnostnorazmerno stanje (manjkrat lastnost). $\mathrm{V}$ primeru desne vezljivosti pa neizglagolski pridevnik izraža lastnost/stanje osebe v razmerju do druge osebe, stvari.

- Dinamična/statična (splošna ali specifična) razmernost, ki označuje nov (skladenjski) pomen, slabi prvotne pomene pridevnikov, tj. specifični pomeni pridevnikov se oslabijo na raven razmernih skladenjskih pomenov. Spreminjanje sintagmatskih lastnosti pa lahko sproži tudi spremembo paradigmatskih lastnosti npr. z ukinjanjem določenih slovničnih in pomenskih kategorij v povedkovodoločilni vlogi nastane nova besedna vrsta povedkovnik. ${ }^{16}$

- Potencialna desna vezljivost določenih neizglagolskih pridevnikov in oslabitev pridevniškega pomena oz. njihovega stanjskorazmernega skladenjskega pomena sta lahko merili za navadno povedkovodoločilno rabo tovrstnih pridevnikov in hkrati potrditev njihove povedkovniškosti. Tako se $\mathrm{z}$ desno vezljivostjo povedkovodoločilnim neizglagolskim pridevnikom odpre možnost prehoda $v$ drugo besedno kategorijo - v povedkovnik. Zanesljivo merilo desne vezljivosti je prosti pridevniški morfem, ki daje prostomorfemskim pridevnikom samo možnost povedkovodoločilne - pridevniške rabe.

${ }^{14}$ Za slovenščino je najnovejša vezljivostna delitev pridevnikov predstavljena v NSS (1982: 57-61) pri obravnavi pridevniške besedne zveze. Na povedkovodoločilno rabo slovenskih pridevnikov pa opozarjata že F. Metelko (1825: 223-226, 233, 238-239), ki skladenjskopomensko opredeli, da 'se pridevnik lahko uporablja kot prilastek ali povedek, npr. Gospodar je zdrav, Gospodar je bil hud na svoje lene služabnike; sem obložen : obloženi mož; Rad sem pri vas; Kratka sprava je boljša kakor dolga pravda, Kdo pozna koga, da bi mu bil enak, Živino imate res lepo, in P. Dajnko (1824: 277-285), npr. Spanje je smrti podobno. Tako Metelko kot Dajnko povzemata primere iz slovnice Dobrovskega (1809-1819). Približno stoletje pozneje je pridevniško vezljivost vzporedno z glagolsko obravnaval A. Breznik (1916: 245-251; 1921: 215-221; 1924: 214-219; 1934: 221226).

15 To ugotavlja že I. Kozlevčar (1969/70: 215) v članku O pridevniku v povedni rabi, kjer povzema, da pridevnik v prilastkovni rabi predvsem pomensko opredeljuje samostalnike, pridevnik v povedni rabi pa navadno pomensko določenemu pojmu prisoja kako lastnost.

${ }^{16}$ Sintagmatsko-paradigmatske potrditve za povedkovnike kot samostojne besedne vrste moramo iskati tudi v drugih slovanskih slovnicah. Primerjalno so upoštevane, po kronološki razvrstitvi, Morfológia slovenského jazyka (1966: 200-201, 205-210), Muvnice češtiny 2 - Tvarosloví (1986: 20-21, 67-68, 75-77, 172-174, 194-202, 253-254, 384387) in Sintaksa hrvatskoga književnog jezika - Nacrt za gramatiku (1986: 35-41, 98, 125-127, 474). 
- Najpomembnejši je razmernostanjski vidik. Tvorčev vidik stanjskih razmerij izraža a) razmerje meritve/mere, b) primerjalno razmerje in c) naklonsko razmerje vrednotenja lastnosti/stanja.

V nadaljevanju so pod $\mathbf{1 . 1}$ zbrani in obravnavani vsi potencialni (prvotni in drugotni) povedkovniki, iz teh so v $\mathbf{1 . 2}$ izbrani samo oz. tipično poved(kov)no rabljeni pridevniki - pravi povedkovniki z že izrazitim kategorialnim pomenom.

\subsection{Povedkovodoločilna raba}

Pri povedkovodoločilnih pridevniških pomenih je v SSKJ v pomenski razlagi ob kvalifikatorskem pojasnilu v povedni rabi poudarjen 'odnos' oz. izraženo 'določeno razmerje'. Pridevniška predložnomorfemska raba uvaja možne (neleksikalizirane) prostomorfemske predloge in s tem neobvezno vezavo. Prevladujoči razmernostanjski skladenjski pomen potrjujeta najpogosteje uporabljana IMETI (razmerje) in BITI (stanje).

Razmernostanjski skladenjski pomen (isti leksem ima različne skladenjske pomene različno vezljivostno zaznamovane). Vse slovarske oznake in pojasnila (po SSKJ) so v okroglih oklepajih.

V nevezavni skupini so poleg drugotnih (premaknjenih ali prenesenih) pomenov še primeri široke in oslabljene rabe. Tako pomensko premaknjena/prenesena kot široka in oslabljena raba izražajo večjo navezanost na poved(kov)no rabo in hkrati tudi višjo stopnjo povedkovniškosti tako označenih pridevniških besed:

čuden 'ki se v vedenju, ravnanju razlikuje od drugih': Po nesreči je postala nekam čudna, Čuden je, ne morem ga razumeti, (ekspr.) Ne bodi no čuden, daj si dopovedati;

divji (ekspr.) 'zelo jezen': Kmalu se vrni, sicer bo oče divji;

dober 'ki glede na kak kriterij, normo, zahtevo ustreza, zadovoljuje': Pritisk imate dober;

dober 'veljaven, uporaben': Voz ni več dober;

dober 'ugodno vpliva, koristi': Počitek je dober;

dober (pog., s širokim pomenskim obsegom): Ta bo dober;

domač 'ki ne kaže strahu v občevanju z ljudmi': Že čez nekaj dni je postal domač; edin (dv. in mn.) 'ki je enakih misli, istega mnenja': Bili so (si) edini;

godov (nar.) 'ki ima, praznuje god': Čez nekaj dni boš godov;

hudičev (ekspr.) 'ki se mu posreči izpeljati tudi kaj navidez nerešljivega': Ta baba je vsa hudičeva;

imeniten (ekspr.) ‘ki v veliki meri izpolnjuje dolžnosti ali delovne zahteve’: Krojač je imeniten;

isti (pog.) 'ki ohranja, ima lastnosti, značilnosti nespremenjene; enak': Nič se ni spremenil, vedno isti je;

izvrsten 'ki v veliki meri izpolnjuje dolžnosti ali delovne zahteve': Fant je izvrsten; jasen (nav. ekspr.) 'ki se lahko popolnoma pričakuje, predvideva': Vsi ti pomisleki so $v$ teh okoliščinah jasni; 
kasen 'ki ima do določenega časa, roka malo, premalo časa; pozen': Bil je kasen; kisel (ekspr.) 'ki izraža, kaže nerazpoloženje, nejevoljo': Že ves popoldan je kisel; lahek / lahkoten (nav. ekspr.) 'ki se duševno in telesno dobro počuti': Odšel je potolažen in lahek/lahkoten; (pren.) tudi: Ta ženska je lahka;

leden (nav. ekspr.) 'ki ima zelo nizko temperaturo': Voda je ledena, Njene roke so ledene;

leden (nav. ekspr.) 'ki vzbuja, povzroča občutek hudega mraza': Pozimi je njegova soba ledena; pren. tudi: Ta človek je leden;

ljudski 'prijazen do preprostih, manj izobraženih slojev prebivalstva': Predsednik je preprost in ljudski;

logičen 'ki se glede na stanje, položaj pričakuje': Ta čustven izbruh je v tem primeru logičen;

nelogičen 'ki ni logičen': Njegova želja je nelogična;

meglen (ekspr.) 'vsebinsko neopredeljen, neizdelan; nejasen': Politični položaj je meglen, Njegovi odgovori so bili megleni, Besedilo je na nekaterih mestih megleno;

mehek (ekspr.) 'obziren, popustljiv, prizanesljiv': Predstojnik je bil sumljivo mehek;

merodajen 'bistven, odločilen': Volja staršev je merodajna;

mesečen (ekspr.) 'ki ponoči v trdnem stanju hodi, kaj dela, ne da bi se tega pozneje spominjal': Taval je po sobi, kot bi bil mesečen, Ah, on je večkrat mesečen; mežav (knjiž.) 'oblačen, mračen': Vreme je bilo mežavo, (pren.) Prevzelo ga je mežavo čustvo;

miren 'ki ne kaže razburjenja, vznemirjenja, napadalnosti': Opozarjali so ljudi, naj bodo mirni;

močen 'ki ima take značilnosti, da more uveljavljati svojo voljo, vpliv': Stranka je bila tedaj že tako močna, da je lahko prevzela oblast;

moderen 'ki je v skladu z modo svojega časa': Rada je moderna;

mogoč 'ki se lahko uresniči, nastopi': Nastop službe je mogoč takoj;

iluzoren (ekspr.) 'nemogoč': Takšni načrti so popolnoma iluzorni;

nemogoč (ekspr.) 'ki zaradi svojega vedenja, ravnanja vzbuja nenaklonjenost, odpor': Ta človek je nemogoč;

nemogoč (ekspr., s širokim pomenskim obsegom) ‘slab, neprimeren': Ima nemogoč plašč, Njegovi prevodi so nemogoči;

nemogoč 'ki ni mogoč': Tu je dvom nemogoč, V tistih krajih je življenje skoraj nemogoče;

možen 'ki se lahko uresniči, nastopi': Nastop službe je možen takoj;

možen 'ki glede na objektivne okoliščine lahko je, obstaja': Na to vprašanje je možen samo en odgovor;

mrakoten (ekspr.) 'negativno, neugodno razpoložen': Zakaj si tako mrakoten?

mrtev (ekspr.) 'ki je umrl': Bil je takoj mrtev;

mučen 'ki zaradi neprimernosti povzroča veliko zadrego, napetost': Prepir je bil za nevtralnega opazovalca zelo mučen;

nabrit (ekspr.) 'ki zna z iznajdljivostjo, duhovitostjo presenetiti, prevarati’: Fant je preveč nabrit; 
naraven 'ki v svojem bistvu ne podleže vplivom okolja': Vedno je naraven;

naraven 'preprost, neprisiljen, neizumetničen': Njegov govor je naraven;

naturen (knjiž.) 'naraven': Zelo naturen človek je;

naroden 'narodno zaveden': Zlasti nižja inteligenca je bila narodna;

navzoč (z oslabljenim pomenom): Inšpektor je bil navzoč pri pouku matematike,

Na sestanku so bili navzoči skoraj vsi člani;

nedotaknjen ' $k i$ je ostal v nespremenjenem položaju ali obliki': Postelja je ostala nedotaknjena;

neopažen 'ki ni opažen': Neopažen je odšel od doma;

nepobiten (knjiž.) 'neovrgljiv, neizpodbiten': Dokaz je nepobiten;

nepomemben (ekspr.) 'ki ni pomemben': Pri tem delu se jim je zdel nepotreben in nepomemben;

nepomemben (knjiž., ekspr.) 'majhen, neznaten': Količina se jim je zdela nepomembna;

nepotreben (ekspr.) 'ki je nastal brez pravega vzroka ali podlage': Te napake so čisto nepotrebne;

neroden (nav. ekspr., s širokim pomenskim obsegom) 'ki povzroča neprijetnosti, težave; slab': Pot je strma in nerodna;

nesmiseln 'ki nima možnosti za uspeh': Njegovo prizadevanje je nesmiselno;

nespameten (ekspr.) 'ki ne ravna v skladu s pametjo, razumom': S tem se ne bo strinjal, saj ni nespameten;

netakten (ekspr.) 'ki mu manjka takta, olike': Fant je nekoliko netakten;

neučakan 'ki težko čaka, pričakuje': Ne bodi tako neučakan;

neugoden 'ki ni ugoden': Čas je bil zelo neugoden;

neumen 'ki ni sposoben hitro dojemati, prodorno misliti': Preveč je neumen;

neumen 'ki ne ravna v skladu z razumom, pametjo': Mlad je še in neumen;

neumen (ekspr.) 'neprimeren, neustrezen': Te pentlje na obleki so prav neumne;

nevaren 'ki lahko povzroči nesrečo, škodo ali kaj slabega, neprijetnega sploh': Ta plin je nevaren;

neroden 'ki pri opravilih ne ravna tako, kot se pričakuje': Pri telovadbi je zelo neroden;

neverjeten (ekspr.) 'ki vzbuja začudenje, presenečenje': Ta človek je neverjeten;

nevšečen 'ki povzroča neprijetnosti, težave': Že ves dan je nevšečen;

nevzdržen (ekspr.) 'neprimeren, slab': Njegov pložaj je nevzdržen;

nevzdržen (nav. ekspr.) 's katerim se ne da soglašati, strinjati': Njegovo stališče je nevzdržno;

normalen 'ki je v skladu z določenimi danimi, splošno veljavnimi zakonitostmi; naraven, pravilen': Utrip srca in telesna temperatura sta normalna;

normalen ' $k i$ ravna, se vede $v$ skladu $z$ določenimi uveljavljenimi, sprejetimi pravili, navadami': Trudil se je, da bi bil normalen kot drugi;

nujen 'ki se mu glede na objektivne okoliščine, zakonitosti ni mogoče izogniti': V takih razmerah je poraz nujen;

obupen 'grd, neprikupen': V tej obleki je obupna;

obvezen 'ki se po določenih normah, predpisih mora storiti, opraviti': Osnovno šolanje je obvezno; 
- ohol (knjiž.) 'ki je ošaben, prevzeten': Do njega je bil ohol;

- okrogel (ekspr.) 'ki ima na telesu precej tolšče, mesa': Bila je precej okrogla;

N okrogel (ekspr.) 'ki je pijan, vinjen': Bil je okrogel;

otročji 'po govorjenju, miselnosti in ravnanju podoben otroku': Otrok je za svoja

leta še otročji;

pasji (ekspr.) 'ki povzroča velike težave, neprijetnosti': To delo je prav pasje;

pičel (nav. ekspr.) 'ki je po vrednosti, količini komaj zadosten, zadovoljiv': Doho-

dek/Pridelek je pičel;

plah 'ki kaže zadržanost, neodločnost': V družbi je plah;

podel 'ki ima zelo negativne lastnosti v moralnem pogledu': Ta človek je podel;

pokojen (knjiž.) 'ki ne čuti notranje napetosti, vznemirjenja; miren': Danes je po-

kojen;

poljuden (zastar.) 'priljubljen, popularen': Kljub ostrim ukrepom je ostal med ljudmi poljuden;

potraten (nav. ekspr.) 'ki po nepotrebnem porablja dobrine': V mladosti je bil bogat in potraten;

resen 'ki se ne šali, smeje': Zakaj si tako resen;

samostojen 'ki je sposoben skrbeti sam zase, se preživljati sam, brez pomoči drugega, zlasti staršev': Trije otroci so že samostojni;

samoten 'ki je brez družbe, brez povezave z drugimi': Počutil se je samotnega, Bila je samotna in bolna;

samoumeven ' $k i$ je razumljiv, umeven sam po sebi': Te stvari so preproste in samoumevne;

siten (ekspr.) 'ki z vztrajnimi, prošnjami, zahtevami skuša priti do česa': Siten moraš biti, pa dosežeš;

slab 'ki ne vpliva ugodno, ne koristi': Daljša prekinitev dela je slaba; slab 'ki je brez moči, onemogel zlasti zaradi bolezni': Bolnik je še slab;

slaboten 'ki je brez moči, onemogel, zlasti zaradi bolezni': Po gripi je še ves slaboten;

smel (knjiž.) 'ki je pogumen, hraber': Postajal je smel;

spodoben 'ki se vede v skladu z moralnimi, družabnimi pravili': Deklica je spodobna, Kopalna obleka ni spodobna;

spodoben (ekspr.) 'primeren, ustrezen': Vreme je bilo kolikor toliko spodobno; spokojen (knjiž.) 'miren': Ostati mora spokojen;

spremenljiv 'ki se spremeni, spreminja': Hitrost je zelo spremenljiva;

srečen (ekspr.) '(zelo) vesel, zadovoljen': Najbolj srečen je, če ga pustijo pri miru; suh (ekspr.) 'brez denarja': Ostal je suh; 
svetel (ekspr.) 'ki vsebuje, izraža pozitivno, ugodno razpoloženje': Njen obraz je bil svetel in miren;

svetel (nav. ekspr.) 'ki je zelo pozitiven, posnemanja vreden': Ta lik je za njih svetel;

svež (ekspr.) 'ki je duševno in telesno zdrav in se dobro počuti': Kljub naporom je ostal svež in veder;

špasen (nižje pog.) 'smešen': Kako si špasen;

takten 'ki primerno ravna, se vede pri občevanju z ljudmi': Bil je prijazen in takten; težek (pog.) 'siten, nadležen': Kadar je pil, je postal težek;

tih 'ki s svojim vedenjem, ravnanjem ne povzroča hrupa': Družba je postala tiha; tih 'ki ne govori dosti': Danes je tih;

topel (ekspr.) 'ki vsebuje, izraža prijaznost, naklonjenost': Ta človek je topel;

trčen (pog.) 'omejen, neumen': Zdel se jim je trčen;

trd (ekspr.) 'pijan, vinjen': Gost je že trd;

trhel (ekspr.) 'onemogel, slab': Bolnik je ves trhel;

trhel (ekspr.) 'slabo utemeljene': Te zahteve so trhle;

udarjen (ekspr.) ‘čudaški, neumen’: Malo je udarjen;

umesten 'ki ustreza danemu položaju, danim okoliščinam': Ta medklic in bil umesten, Jeza je bila umestna;

uraden (ekspr.) 'ki je zadržan': Ne bodi tako uraden; nasproti: uradni predstavnik/ naziv/ postopek;

važen (žarg.) 'bahav, postavljaški': Postal je važen;

večen (ekspr.) 'ki nepričakovano dolgo ohranjajo svoje lastnosti, uporabnost': Ti čevlji so večni;

vesel 'ki je v stanju veselja': Vesel je bil, da bi zavriskal;

visokorasel 'ki je visoko raščen': Fant je visokorasel;

votel (ekspr.) ‘ki je notranje, vsebinsko prazen': Ta človek je votel;

votel (ekspr.) 'ki je neutemeljen, nedoločen': Ta strah je votel;

zdrav ' $k i$ je $v$ stanju telesnega in duševnega dobrega počutja, brez motenj v delovanju organizma': Ostal je zdrav;

zlodejev (ekspr.) 'ki se mu posreči izpeljati tudi kaj navidez nerešljivega': Ves zlodejev je;

žalosten 'ki je v stanju žalosti': Žalosten je zaradi smrti očeta;

živ (ekspr.) 'ki se zaradi velike prožnosti težko oblikuje, uredi': Po umivanju so lasje zelo živi;

življenjski 'ki izhaja iz resničnosti, iz življenja': Ta človek je zelo življenjski, Pouk je življenjski;

neskl.

fair (prid. neskl.) 'ki je v skladu z določenimi normami': To ni fair;

flegma (prid. neskl., pog.) 'flegmatičen': On je zelo flegma;

fuč (prid. neskl., pog., ekspr.) 'uničen, propadel': Čevlji so že fuč;

fuč (prid. neskl., pog., ekspr.) 'ki je minil, prešel': Njena mladost je za zmeraj fuč;

kaput (prid. neskl., nižje pog.) 'mrtev, ubit': Če ne bežite, boste kaput;

kaput (prid. neskl., nižje pog.) 'uničen, razbit': Avto je kaput; 


\section{$R_{\text {odstio }}$}

nesvoj 'nesamozavesten, neodločen': Od skrbi in dvomov je ves nesvoj;

trapast 'zmeden': Kar trapast je od skrbi;

premrzel (ekspr.) 'ki je preveč neprijazen, sovražen': Do staršev je premrzel;

\section{$\mathrm{D}$}

dorasel (z dajalnikom) 'ki je kos čemu': Mladina je dorasla delu/nalogam; drag (z dajalnikom) 'do katerega ima kdo pozitiven čustven odnos': Ta človek mu je zelo drag;

enak ( $\mathrm{z}$ dajalnikom) ' $\mathrm{ki} \mathrm{v}$ primerjavi drugega $\mathrm{z}$ drugim nobeden nima prednosti, večjih pravic': Njegov uspeh je enak ničli, Lira je enaka dvema tolarjema; gorek (ekspr., z dajalnikom) 'nenaklonjen, sovražen': Gorek mu je;

jasen (navadno $z$ dajalnikom) 'ki se popolnoma razume, dojame, spozna': Po teh dogodkih so mu nekatere stvari jasne;

lasten (knjiž., z dajalnikom) 'značilen, tipičen': Z naglico, ki je lastna trmastim ljudem, je odšla; 
ljub (z dajalnikom) 'do katerega ima kdo zelo pozitiven čustveni odnos': Ta spomin je vsem ljub, Domača hiša mu je bila ljuba;

neljub (z dajalnikom) 'ki (komu) ni ljub': Ta človek mu je iz več razlogov neljub; mil (knjiž., z dajalnikom) 'drag, ljub’: Vedno mu je bil zelo mil;

naklonjen (z dajalnikom) 'ki ima, kaže pozitiven odnos do koga': Predstojnik mu je naklonjen, Naklonjeni so naši ureditvi;

nenaklonjen ( $\mathrm{z}$ dajalnikom) 'ki ni naklonjen': Čutili so, da jim je nenaklonjen, Komisija je postajala tej zamisli vedno bolj nenaklonjena;

nasproten ' $\mathrm{ki}$ je, nastopa proti delu, mnenju, naziranju drugega': Kdo mi je naspro-

ten, Izjave prič so si nasprotne, To je nasprotno vsem našim prizadevanjem;

neprijeten 'ki ni prijeten': Te besede so mu neprijetne;

neprijeten (z dajalnikom) 'ki ne ugaja, ni všeč’: Njegovo izražanje mu je bilo neprijetno;

nerazumljiv ( $z$ dajalnikom) 'ki se ne da razumeti, dojeti': Razlaga je bila učencem nerazumljiva;

nevšečen (star.) 'ki (komu) ni všeč, ne ugaja': Že na prvi pogled jim je bil nevšečen, To delo mu je nevšečno;

neznan (z dajalnikom) 'ki ni znan': Po imenu mu je neznan, (ekspr.) Skrbi so mu neznane;

odgovoren ' $\mathrm{ki}$ je v takem odnosu do koga, da mu mora dajati pojasnilo, utemeljitev za svoje delo, ravnanje': Izvršilni organi so odgovorni skupščini;

podložen (z dajalnikom) 'podrejen': Naše dežele so bile podložne Avstro-Ogrski, Kmet je bil podložen graščaku;

podvržen (z dajalnikom) 'izraža hotenje, voljo do določenega dela, dejavnosti': Zelo je podvržen branju;

podvržen (z dajalnikom) 'izraža možnost hitrejšega, pogostejšega obolenja': Povržen je pljučnici;

prijazen (knjiž., z dajalnikom) 'naklonjen': Čas mu ni bil prijazen, Sile so bile človeku prijazne;

privržen (z dajalnikom) ' $k$ i ima zelo pozitiven odnos do koga, zlasti zaradi njegovih idej, nazorov': Bil je zelo privržen voditelju in idejam revolucije;

sovražen (z dajalnikom) 'usmerjen, delujoč proti temu, kar izraža dopolnilo’: Ta človek je sovražen napredku;

umeven 'ki se da razumeti, dojeti': Navodila morajo biti vsem umevna;

umljiv (knjiž.) 'razumljiv, jasen': Vse besede so mu umljive;

veren (zastar.) 'zvest, vdan': Ostal je veren zemlji;

všeč (z dajalnikom) 'izraža, da kaj ustreza okusu, željam, zahtevam koga': Darilo jim je všeč;

znan 'katerega lastnosti, značinosti kdo osebno pozna iz izkustva, študija': Vsebina knjige mu je bila le deloma znana;

zvest (z dajalnikom) 'ki kaj vztrajno dela; ki česa ne opusti, ne preneha upoštevati':

Je zvest načelom/ navadi;

$\mathrm{D}+\mathrm{T}$

dolžen 'ki je obvezan komu kaj izkazovati, storiti': Dolžen sem mu hvaležnost; 
$\sim T_{n a / z a}$

hud 'imeti z okoljem odklonilen odnos': Še je hud nanj;

imun (med.) 'odporen proti določeni okužbi': Po ozdravitvi ostane za vse življenje imun;

karakterističen 'ki osebo, stvar, pojav pomembno opredeljuje, določa; značilen, tipičen': Za to fazo kapitalizma je karakteristično vmešavanje države $v$ gospodarstvo;

nevaren (ekspr.) 'ljubezensko, spolno zelo privlačen': Je nevaren za žensko srce; obupen 'ki ne vzbuja upanja': Ta negotovost je zanj obupna;

pretrapast (pog.) 'preveč neumen, nespameten': Pretrapasta je, da bi to razumela, To so pretrapaste izjave za tako resnega človeka;

prezrel 'ki je preveč zrel': Fant je prezrel za kaj takega;

sončen (ekspr.) 'za človeka zelo prijeten': Ta dan je bil zanj sončen;

vreden 'izraža značilnost česa glede na zadovoljevanje določenih potreb': Ta prstan je zame veliko vreden, ${ }^{17}$

vroč (ekspr.) 'navdušen, vnet': Bil je vroč za pravično stvar;

$\mathrm{M}_{\text {pri/vna }}$

Nepotreben 'ki ni potreben': Pri tem delu si nepotreben;

prenagel (nav. ekspr.) 'ki reagira preveč hitro in navadno nepremišljeno': V sodbah je prenagel';

znan 'ki obstaja na kakem prostoru, v kakem času': Ti običaji so znani na kmetih;

$\mathrm{Ne}$

voljen (z nedoločnikom) ‘ki ima voljo, je pripravljen za kaj': Je voljen delati/pomagati.

\subsubsection{Neobvezna vezava $z$ neleksikaliziranimi predložnimi morfemi}

Neobvezna prostomorfemska raba oz. neobvezna desna vezljivost $\mathrm{v}$ istem skladenjskem pomenu še dodatno potrjuje pogosto uporabo določenih pridevniških besed v specifičnih povedkovodoločilnih vlogah. (Poševnice // so oznaka za neobveznovezavnega udeleženca $v$ določenem sklonu):

- razmernostanjski/-tvorni pomen z/namenskostjo/ciljnostjo/

$/ \mathrm{T}_{\text {na/za }}$ l-razmernostanjski duševnostni pomen:

divji / divji na (ekspr.) 'zelo jezen': Ves je divji / Nanj je ves divji;

dober / dober za 'ki glede na kak kriterij, normo, zahtevo ustreza, koristi': biti dober / biti dober za koga/kaj/kam/za koliko časa;

lušten / lušten za 'prijeten, zabaven': Razpoloženje je bilo luštno, Bil je lušten za družbo;

moderen / moderen za 'ki upošteva najnovejše norme svojega časa': Pisatelj jim ni dovolj moderen, Njegova glasba je za mnoge premalo moderna;

${ }^{17}$ Beseda je npr. besednovrstno že opredeljena kot povedkovnik (Vidovič Muha 1988: 130). 
nared / nared za (prid. neskl., knjiž.) 'pripravljen': Vedno so nared, Sani so nared za vožnjo;

ugoden / ugoden za 'ki zaradi skladnosti svojih lastnosti, značilnosti s hotenjem, željami koga omogoča uspešno uresničitev določenega dejanja': Trenutek je ugoden, Vreme je ugodno za košnjo;

neugoden / neugoden za 'ki ni ugoden': Čas je bil zelo neugoden, Čas je bil zelo neugoden za košnjo;

neumen /neumen za 'ki ni sposoben hitro dojemati, prodorno misliti': Preveč je neumen, Preveč je neumen za šolo;

preneumen / preneumen za 'preveč neumen': Je še premlad in preneumen, Preneumen je za tako delo;

potreben / potreben za 'brez katerega kaj ne more biti, obstajati': Otroku je potrebna ljubezen, Za življenje je potreben kisik;

primeren / primeren za ' $k$ i je v skladu z določenimi normami, pravili': Njegovo vedenje ni primerno, Ta obleka za gledališče ni primerna;

simptomatičen / simptomatičen za (knjiž.) 'značilen, tipičen': Obnašanje je simptomatično, Ta kriza je simptomatična za takratne razmere;

slep / slep za 'ki ni sposoben zaznamovati svetlobe, barv': Fant je od rojstva slep, Slep je za barve;

strašen / strašen za 'strašljiv': Ta je kar strašen, Zgodba je preveč strašna za otroke; svet / svet za (ekspr.) 'ki ima za koga zelo veliko vrednost zaradi svoje povezanosti s čim zelo cenjenim, ljubljenim': Zakon jim je svet in nedotakljiv, Ta kraj je zanj svet;

važen / važen za 'pomemben, tehten': Novica je važna, Prehrana je važna za razvoj otroka;

zanimiv / zanimiv za 'primeren, sprejemljiv, vabljiv': Cene so bile zanje zanimive, Ponudba je bila zanje zanimiva;

$/ \mathrm{R}_{(\mathrm{do})} / \mathrm{D} / \mathrm{T}_{\mathrm{za}} /$ - razmernotvorni duševnostni pomen:

kriv / kriv za 'ki je povzročil kaj slabega, neprijetnega, nezaželenega': On je kriv smrti, Oče je kriv za tako stanje;

sokriv / sokriv za 'ki je skupaj s kom kriv česa': Je sokriv prometne nesreče, Tudi on je sokriv za neuspeh;

nevaren / nevaren za 'ki lahko povzroči nesrečo, škodo ali kaj slabega, neprijetnega sploh': Je nevaren družbi, Je nevaren za družbo;

dolžen / dolžen za 'ki je obvezan komu kaj izkazovati, storiti': Na vse strani je dolžen, Družbi je dolžen za vzgojo, Dolžni ste (mi) najemnino za pol leta;

odprt / odprt za / odprt do 'ki ima do ljudi in pojavov razumevajoč, strpen odnos': Ta človek je odprt in iskren, Kot človek je odprt za vsakogar, Mladi so zelo odprti do sveta okrog sebe;

prijeten / prijeten za 'ki ima, kaže v odnosu do ljudi pozitivne lastnosti': Njegova žena je prijetna, Bil je prijeten za družbo;

zmožen / zmožen za 'ki ima lastnosti, značilnosti, potrebne za dobro opravljanje kake dejavnosti': Ni zmožen pametne misli, Je zmožen za delo;

živ / živ za (ekspr.) 'ki kaže veliko nagnjenje do spolnosti': Preveč je živa, Premalo je živ zanjo; 


\section{- razmernostanjski prostorsko-časovni pomen:}

moker / moker do / moker od 'polit ali prepojen z vodo ali drugo tekočino': (evfem.) Otrok je moker, Bil je moker do kolen, (ekspr.) 'znojen': Od napora je postal moker;

obraten / obraten od 'glede na potek dejanja': Časovno zaporedje je lahko obratno, Časovno zaporedje je lahko obratno od navedenega;

\section{$/ \mathrm{D}_{\text {proti }} /$ - razmernostanjski duševnostni pomen:}

imun / imun proti (med.) 'odporen proti določeni okužbi': Po ozdravitvi ostane za vse življenje imun, Za vse življenje je imun proti škrlatinki;

$/ \mathrm{M}_{\mathrm{v} / \mathrm{na} / \mathrm{pri}}$ I

-okoliščinskost (prostorsko-časovna/duševnostna):

običajen / običajen $\mathrm{v} /$ običajen na 'ki se pogosto pojavlja na istem mestu, $\mathrm{v}$ enaki obliki, na enak način': Ti zastoji v prometu so običajni, Te stvari so na deželi/v mestu že čisto običajne;

odličen / odličen na 'ki v zelo veliki meri izpolnjuje dolžnosti ali delovne zahteve':

$\mathrm{Na}$ treningu je bil odličen;

priden / priden pri / priden v 'ki izpolnjuje dolžnosti, zahteve': Sin je zelo priden,

Pri delu je priden, $V$ šoli je priden; 
Pri plesu je bila lahka;

nagel / nagel v (nav. ekspr.) 'ki reagira hitro, navadno nepremišljeno': Je trmast in nagel, Je nagel v sodbi;

prenagel / prenagel v (nav. ekspr.) 'ki reagira preveč hitro in navadno nepremišljeno': Je prenagel, V sodbah je prenagel;

\section{- lastnost (telesna/duševna):}

lep / lep v 'ki ima v estetskem pogledu pozitivne lastnosti': Mnogo lepši je od nje, Bila je lepa $v$ telo, $v$ glavo pa ne;

slab / slab v 'ki glede na kak kriterij, normo, zahtevo ne ustreza, ne zadovoljuje': Naloga je slaba, Učenka je v matematiki slaba;

trden / trden v 'ki ne omahuje': Kljub prepričanju je ostal trden, Bil je trden v svojih sklepih;

$/ \mathrm{O}_{z / s} /$ - razmernostanjski duševnostni pomen:

domač / domač z/s / domač pri 'ki ne kaže strahu v občevanju z ljudmi': biti domač / biti z njim čisto domača / biti domač pri kom;

mehek / mehek z/s (ekspr.) 'obziren, popustljiv, prizanesljiv': Predstojnik je bil sumljivo mehek, Upravnik je bil mehek s kaznjenci;

sladek / sladek z/s (ekspr.) 'zelo, pretirano prijazen': Je ves sladek, Na videz so bili sladki z njim;

soglasen / soglasen z/s 'ki ima enako mnenje o čem, stališče do česa': Udeleženci konference so bili soglasni glede glavnih vprašanj, Niso bili soglasni z njegovim pravopisnim načrtom;

tečen / tečen z/s (ekspr.) 'ki z neprimernim vedenjem, govorjenjem povzroča komu neprijetnosti, slabo voljo': Je tečen, Je tečen s svojimi vprašanji;

$/ \mathrm{O}_{\text {pred }} /$ - razmernostanjski duševnostni pomen:

varen / varen pred ' $\mathrm{ki}$ je $\mathrm{v}$ takem stanju, položaju, da mu ne grozi nevarnost, kaj neprijetnega': Doma je varen, Varen je pred radovednimi pogledi/pred ognjem;

\section{$/ \mathrm{T}_{\mathrm{za}} / \mathrm{O}_{\mathrm{z} / \mathrm{s}} /$ - razmernostanjski prostorsko-časovni pomen:}

kasen / kasen za / kasen z/s 'ki ima do določenega časa, roka malo, premalo časa; pozen': Bil je kasen, Kasen je za v gledališče, Kasen je z opravičilom;

pozen / pozen za / pozen z/s 'ki ima do določenega časa, roka malo, premalo časa': Zaspal je, zato je pozen, Pozni ste za gledališče, Pozen si z opravičilom; zgoden / zgoden za /zgoden z/s ' $\mathrm{ki}$ ima do določenega časa, roka dovolj, veliko časa': Danes je zgoden, Zgoden je za gledališče; Danes je zgodna s kavo;

$/ \mathrm{M}_{\mathrm{o} / \mathrm{v}} / \mathrm{O}_{\mathrm{z} / \mathrm{s}} /$ - razmernostanjski duševnostni pomen:

edin / edin o / edin v / edin $\mathrm{z} / \mathrm{s}$ (dv. in mn.) 'ki je enakih misli, istega mnenja': Bili so (si) edini, Niso edini o tem/v tem, Edini so z njim. 


\subsubsection{Obvezna vezava $z$ leksikaliziranim predložnim morfemom}

Obvezna raba prostega predložnega morfema prisoja pridevniškim besedam obvezno prostomorfemsko rabo in s tem specifični glagolski skladenjski pomen, ki dopušča samo povedkovodoločilno rabo.

\section{$\mathrm{T}_{\mathrm{na} / \mathrm{za} / \mathrm{v}}$ - razmernotvorni/-stanjski pomen:}

divji na (ekspr.) 'zelo jezen': Ves divji je nanj;

jezen na 'ki ima negativen, odklonilen odnos do koga/česa': Jezen je na starše/ stripe;

lakomen na 'ki čuti, ima strastno željo po kaki jedi': Polhi so lakomni na hruške; ljubosumen na 'ki čuti nezadovoljnost zaradi uspehov, prednosti koga': Mož je bil ljubosumen na soseda, Ljubosumen je na njihove uspehe; mrtev na (pog., ekspr.) 'zelo rad imeti': (Ves) mrtev je na klobase;

ponosen na 'zelo zadovoljen zaradi pozitivnih lastnosti sebe ali drugega': Ponosen je na svojo modrost, uspehe; udarjen na (pog., ekspr.) 'ki čuti, ima veliko željo po tem, kar izraža določilo':

Udarjen je na denar; volčji na (ekspr.) 'ki čuti, ima strastno željo po čem': Je volčji na denar/gobe; dovzeten za 'ki je sposoben dojemati, občutiti': Je dovzeten za glasbo;

gluh za (ekspr.) 'ki noče dojeti, upoštevati česa': Bil je gluh za vsak nasvet/za vse; interesanten za (publ.) 'od katerega se glede na kak kriterij pričakuje uspeh, korist, primeren': Ti kraji so interesantni za turizem zaradi ugodne klime;

koristen za 'ki daje, prinaša ugodne, pozitivne posledice': Sadje je koristno za prebavo;

len za 'ki nima želje, volje za kako opravilo': On je len za hojo;

merodajen za 'pristojen, pooblaščen': Za to stvar je merodajno sodišče;

nujen za 'brez katerega določenega dela, dejavnosti ni mogoče zadovoljivo opravljati': Za to delo je nujna čelada;

obvezen za 'ki se po določenih normah, predpisih mora narediti, storiti, opraviti':

Udeležba na predavanjih je za študente obvezna;

odgovoren za 'dolžen sprejeti sankcije, dati opravičilo': Ne more biti odgovoren za dejanja;

poklican za (nav. ekspr.) 'obvezan komu kaj izkazovati, storiti; dolžen': Odbor je poklican za ureditev;

poklican za (nav. ekspr.) 'izbran, določen': Človek je poklican za velike stvari;

pomemben za 'ki je sam po sebi ali v odnosu do drugega tak, da lahko vpliva na določena dejstva': Ta slikar je pomemben za razvoj umetnosti, Ta tekma je pomembna za uvrstitev v finale;

pooblaščen za 'ki ima uradno veljavno pravico opravljati kako (pravno) dejanje namesto koga ali v imenu koga': Je pooblaščen za to opravilo;

poskrbljen za 'biti uspešen za v prizadevanju priti do česa': Za izobrazbo otrok je poskrbljeno, $\mathrm{V}$ taki stavbi je poskrbljeno za prepih;

potreben za 'brez katerega določenega dela, dejavnosti ni mogoče zadovoljivo opravljati': Za to je potreben določen čas; 
presvoj za (knjiž., redko) ‘preveč samostojen, preveč neupogljiv': Za tako vlogo je presvoj;

priden za 'ki ima željo, voljo za kako opravilo': Je priden za učenje;

prikladen za 'primeren': Bil je prikladen za družabnika;

primeren za 'ki ima zaželene lastnosti, se sklada s pričakovanim': Je primeren za voznika tovornjaka;

pripraven za 'primeren, ustrezen za kak namen sploh': Je pripravna za delo; pristojen $\mathrm{za}$ ' $\mathrm{ki}$ ima $\mathrm{z}$ zakonom dano pravico in dolžnost opravljati kako (pravno) dejanje, odločati o čem': Je pristojen za reševanje teh vprašanj;

rojen za (ekspr.) 'ki ima veliko mero sposobnosti, lastnosti za kaj': On je rojen za pilota; Ni bil rojen za meščansko življenje, Bil je kakor rojen za to vlogo; slep za (ekspr.) 'ki ne opazi, dojame česa': Bil je slep za lepote narave; sposoben za ' $\mathrm{ki}$ ima lastnosti, značilnosti, potrebne za dobro opravljanje kake dejavnosti': Ni sposoben za to delo;

sprejemljiv za 'ki je sposoben sprejemati; dovzeten': Mož je sprejemljiv za novosti; tipičen za 'ki ima take lastnosti, značilnosti, da osebo, stvar, pojav uvršča v posebno skupino iste vrste': Znaki so tipični za bolezen;

usoden za (ekspr.) 'ki ima velik, odločilen pomen za nadaljnji potek česa': Dogodki so bili usodni za ljudi;

voljen za 'pripraven sposoben': Bil je voljen za vse;

zanimiv za (publ.) 'primeren, sprejemljiv': Ta predlog za nas ni zanimiv;

značilen za ' $k i$ ima izrazite bistvene lastnosti istovrstnih stvari, pojavov': Stavba je značilna za secesijo;

zoprn za 'ki ima, kaže v odnosu do ljudi zelo negativne, neprijetne lastnosti': Bil zoprn za družbo;

zrel za 'glede na telesno, duševno razvitost sposoben za kaj': Otrok je zrel za šolo. primoran $\mathrm{v}$ 'prisiljen': $\mathrm{V}$ to dejanje je bil primoran;

prisiljen v 'ki ne kaže resničnega razpoloženja': Prisiljen je bil v akcijo; uklet v (ekspr.) 'ujet v kaj, iz česar se ne da rešiti’: Je uklet v molk/nasilje/trpljenje;

$\mathrm{R}_{\text {od/do }}$-razmernostanjski duševnostnostni pomen:

blazen od (ekspr.) 'zaradi močnega čustva zelo razburjen': biti blazen od obupa, veselja, žalosti;

bolan od (ekspr.) 'zaradi močnega čustva prizadet, vznemirjen': Kar bolan je od sreče;

neumen od (ekspr.) 'zaradi močnega čustva zelo razburjen': Ves neumen je od veselja; odvisen od ' $k i$ je v takem odnosu do koga, da ta skrbi za njegove potrebe': Mladič je dolgo odvisen od svoje matere;

svetel od (ekspr.) 'pozitivno, ugodno razpoložen': Bil je ves svetel od nje; mlačen do 'ki nima, ne kaže zavzetosti za kaj': Do družbenih dogajanj ostajajo mlačni;

mrzel do (ekspr.) 'ki vsebuje, izraža veliko nenaklonjenost, odklanjanje; neprijazen, sovražen': Do njega je bila zmerja mrzla;

pošten do 'ki ravna v skladu $z$ določenimi normami, priznanimi načeli': Predstojnik je bil do vseh pošten; 
upravičen do 'ki ima pravico do česa': Je upravičen do otroškega dodatka;

$\mathrm{M}_{\mathrm{v} / \mathrm{pr} / \mathrm{ina} / \mathrm{po}}$-okoliščinskost (prostorsko-časovna/duševnostna):

izveden $v$ 'ki kako stroko, dejavnost dobro obvlada': Je izveden v državniških zadevah;

navzoč pri/na (z oslabljenim pomenom) ' $k$ j je $v$ določenem času na določenem mestu': Inšpektor je bil navzoč pri pouku matematike, Na sestanku so bili navzoči vsi člani;

znan po 'ki vzbudi v osebku občutek identičnosti s tem, kar pozna, ve': Znan mi je le po obrazu;

$\mathrm{O}_{z / s}$-razmernostanjski duševnostni pomen:

identičen $\mathrm{z} / \mathrm{s}$ 'ki se v lastnostih, značilnostih ujema z drugim': S takšnimi trditvami postaja identičen s svojimi kritiki;

ljubezniv z/s (ekspr.) 'ki izkazuje osebi drugega spola ljubezen, naklonjenost': Dekle ni bilo več tako ljubeznivo $\mathrm{z}$ njim;

prehud z/s 'preveč hud': Ne bodi prehud z njo;

skladen z/s 'ki ima prav take lastnosti, značilnosti, kot so določene, se pričakujejo glede na izbrano merilo urejenosti, pravilnosti': Njegova dejanja so skladna z govorjenjem;

skop z/s (ekspr., z orodnikom) 'ki daje, porablja zelo malo tega, kar izraža dopolnilo': Je skop z denarjem / s plačilom;

solidaren $\mathrm{z} / \mathrm{s}$ 'ki podpira, odobrava ravnanje, mnenje koga': Rudarji so solidarni s stavkajočimi;

sorazmeren z/s 'ki ima glede na dejstvo, s katerim se primerja, ustrezno mero, količino': Fantova glava ni bila sorazmerna z njegovo veliko postavo, Presežek je bil sorazmeren $z$ deležem zaposlenih;

udarjen z/s (pog., ekspr.) 'ki označuje stanje, ki ga izraža določilo': Udarjen je s slepoto;

ubran z/s 'ki s čim sestavlja urejeno, prijetno celoto': Nakit mora biti ubran z obleko;

zadovoljen z/s 'ki ima pozitiven, odobravajoč odnos do koga, česa': Gospodar je zadovoljen z najetimi delavci, Bil je z malim zadovoljen;

združen z/s 'ki vključuje to, kar izraža dopolnilo': S tem je združen neprijeten občutek;

znan $\mathrm{z} / \mathrm{s}$ 's katerim se kdo pozna in ima z njim osebne stike': Bil je znan z vsemi veljaki v kraju.

\section{Sopomenske predložnosklonske različice izražajo razmernostanjski dušev- nostni pomen:}

$\mathrm{T}_{\mathrm{za}} / \mathrm{R}_{\mathrm{do}}$

imun za / imun do (knjiž.) 'neobčuljiv, odporen': Imun je za vse negativne vplive, Imen je do dogajanja na trgu; 
$\mathrm{T}_{\text {na }} / \mathrm{R}_{\mathrm{od}}$

nor na / nor od 'zaradi močnega čustva zelo razburjen': Čisto nor je na konje; Ves nor je od obupa/veselja;

$\mathrm{R}_{\mathrm{od}} / \mathrm{O}_{\mathrm{z} / \mathrm{s}}$

pogojen od / pogojen $\mathrm{z} / \mathrm{s}$ ' $\mathrm{ki}$ je $\mathrm{v}$ takem odnosu do česa, da to mogoča njegovo uresničitev, določa stopnjo, lastnosti; odvisen': Sporazum je pogojen od raznih momentov, Njegovo delovanje je pogojeno $\mathrm{z}$ družbeno usmerjenostjo;

$\mathrm{R}_{\mathrm{do}} / \mathrm{O}_{z / \mathrm{s}}$

ljubezniv do / ljubezniv z/s (ekspr.) 'ki vsebuje, izraža naklonjen čustveni odnos': Prodajalka je bila ljubezniva do kupcev, Zdravnik je ljubezniv z bolniki; premrzel do / premrzel z/s (ekspr.) 'preveč mrzel': Je premrzel do njega; Je premrzel z njim;

$\mathrm{T}_{\mathrm{za}} / \mathrm{M}_{\mathrm{po}} / \mathrm{O}_{\mathrm{pred}} / \mathrm{O}_{z / \mathrm{s}}$

enak za / enak po / enak pred / enak z/s ' $k i$ je v primerjavi drugega $\mathrm{z}$ drugim nobeden nima prednosti, večjih pravic': Zakon je za vse enak, Po zabavnosti mu je enak, Pred zakonom so vsi enaki, Je enak z drugimi.

\subsection{Pridevniški obvezno- in neobveznovezavni povedkovniki}

Pri prvotni pomenskoskadenjsko opravičljivi povedkovodoločilni vlogi, ki je pogosto potrjena še s prostopredložnomorfemsko rabo povedkovodoločilni (stavčnopoložajni razmernotvorni/razmernostanjski) pomen preide v povedkovniški (kategorialni) pomen. Med slovničnimi in pomenskimi kategorijami, ki poudarjajo povedkovniškost, so: nesklonskost ( $\Rightarrow$ neujemalnost in netipična prilastkovna raba), naklonskost in skladenjska oz. povedkovodoločilna pomenskost ( $\Rightarrow$ drugotni, oslabljeni ali široki pomeni pridevnikov).

O pravih povedkovnikih lahko govorimo pri pridevniških besedah s prevladujočimi razmernotvornimi ali razmernostanjskimi pomeni:

\section{1) Vezavni:}

$\mathrm{R}$

deležen ( z rodilnikom) 'ki kaj dobi, doživi': biti deležen pozornosti, sreče, sovraštva;

gotov 'prepričan, trden': Ni bil gotov, kaj bo z njim, Bil je gotov zmage;

kriv 'ki je povzročil kaj slabega, neprijetnega, nezaželenega': Te nesreče je on kriv, Je kriv smrti prijatelja;

navajen 'izraža lastnost, ki postane zaradi ponavljanja': Navajen je dela;

nevreden (nav. ekspr., z rodilnikom) 'ki ni vreden, ne zasluži česa': Je nevreden ljubezni, občudovanja, zaupanja;

potreben 'ki je v stanju, ko mora kaj dobiti glede na pomanjkanje česa, okoliščine': Je potreben denarja, pomoči; 
želen (z rodilnikom) 'ki ima (veliko) željo po čem': Bil je želen dela/dobrih jedi;

\section{$\mathrm{D}$}

dorasel (z dajalnikom) 'ki je kos čemu': Mladina je dorasla delu/nalogam; drag (z dajalnikom) 'do katerega ima kdo pozitiven čustven odnos': Ta človek mu je zelo drag;

gorek (ekspr., $z$ dajalnikom) 'nenaklonjen, sovražen': Gorek mu je;

lasten (knjiž., $\mathrm{z}$ dajalnikom) 'značilen, tipičen': $Z$ naglico, ki je lastna trmastim ljudem, je odšla;

ljub (z dajalnikom) 'do katerega ima kdo zelo pozitiven čustveni odnos': Ta spomin je vsem ljub, Domača hiša mu je bila ljuba;

neljub (z dajalnikom) 'ki (komu) ni ljub': Ta človek mu je iz več razlogov neljub; mil (knjiž., z dajalnikom) 'drag, ljub': Vedno mu je bil zelo mil;

naklonjen (z dajalnikom) 'ki ima, kaže pozitiven odnos do koga': Predstojnik mu je naklonjen, Naklonjeni so naši ureditvi;

nenaklonjen (z dajalnikom) 'ki ni naklonjen': Čutili so, da jim je nenaklonjen, Komisija je postajala tej zamisli vedno bolj nenaklonjena;

nasproten 'ki je, nastopa proti delu, mnenju, naziranju drugega': Kdo mi je nasproten, Izjave prič so si nasprotne, To je nasprotno vsem našim prizadevanjem; podvržen (z dajalnikom) 'izraža hotenje, voljo do določenega dela, dejavnosti': Zelo je podvržen branju;

podvržen (z dajalnikom) 'izraža možnost hitrejšega, pogostejšega obolenja': Povržen je pljučnici;

privržen (z dajalnikom) 'ki ima zelo pozitiven odnos do koga, zlasti zaradi njegovih idej, nazorov': Bil je zelo privržen voditelju in idejam revolucije;

sovražen (z dajalnikom) 'usmerjen, delujoč proti temu, kar izraža dopolnilo': Ta človek je sovražen napredku;

veren (zastar.) 'zvest, vdan': Ostal je veren zemlji;

$\mathrm{D}+\mathrm{T}_{(\mathrm{za})}$

dolžen 'ki je obvezan komu kaj izkazovati, storiti': Dolžen sem mu hvaležnost;

dolžen / dolžen za 'ki je obvezan komu kaj izkazovati, storiti': Na vse strani je dolžen, Družbe je dolžen za vzgojo, Dolžni ste (mi) najemnino za pol leta.

\section{2) Nevezavni:}

godov (nar.) 'ki ima, praznuje god': Čez nekaj dni boš godov;

isti (pog.) 'ki ohranja, ima lastnosti, značilnosti nespremenjene; enak': Nič se ni spremenil, vedno isti je;

kisel (ekspr.) 'ki izraža, kaže nerazpoloženje, nejevoljo': Že ves popoldan je kisel; leden (nav. ekspr.) 'ki ima zelo nizko temperaturo': Voda je ledena, Njene roke so ledene;

leden (nav. ekspr.) 'ki vzbuja, povzroča občutek hudega mraza': Pozimi je njegova soba ledena; 
ljudski 'prijazen do preprostih, manj izobraženih slojev prebivalstva': Predsednik je preprost in ljudski;

mehek (ekspr.) 'obziren, popustljiv, prizanesljiv': Predstojnik je bil sumljivo mehek; mogoč 'ki se lahko uresniči, nastopi': Nastop službe je mogoč takoj; nemogoč (ekspr.) 'ki zaradi svojega vedenja, ravnanja vzbuja nenaklonjenost, odpor': Ta človek je nemogoč;

nemogoč 'ki ni mogoč': Tu je dvom nemogoč, V tistih krajih je življenje skoraj nemogoče;

nemogoč (ekspr., s širokim pomenskim obsegom) ‘slab, neprimeren': Njegovi prevodi so nemogoči (nasproti: Ima nemogoč plašč);

možen 'ki se lahko uresniči, nastopi': Nastop službe je možen takoj; naraven 'ki v svojem bistvu ne podleže vplivom okolja': Vedno je naraven;

naraven 'preprost, neprisiljen, neizumetničen': Njegov govor je naraven; naturen (knjiž.) 'naraven': Zelo naturen človek je; naroden 'narodno zaveden': Zlasti nižja inteligenca je bila narodna; okrogel (ekspr.) 'ki je pijan, vinjen': Bil je okrogel; topel (ekspr.) 'ki vsebuje, izraža prijaznost, naklonjenost': Ta človek je topel; udarjen (ekspr.) ‘čudaški, neumen': Malo je udarjen; življenjski 'ki izhaja iz resničnosti, iz življenja': Ta človek je zelo življenjski, Pouk je življenjski.

\section{1) Nesklonski:}

fuč (prid. neskl., pog., ekspr.) 'uničen, propadel': Čevlji so že fuč; fuč (prid. neskl., pog., ekspr.) 'ki je minil, prešel': Njena mladost je za zmeraj fuč; kaput (prid. neskl., nižje pog.) 'mrtev, ubit': Če ne bežite, boste kaput; kaput (prid. neskl., nižje pog.) 'uničen, razbit': Avto je kaput; kontent (prid. neskl., nižje pog.) 'zadovoljen': Takoj je bila kontent; kontent (prid.neskl., nižje pog.) 'zadovoljen': Takoj je bila kontent; kvit (prid, neskl., nižje pog.) 'končan': Ona je kvit; portabel: (prid. neskl., žarg., adm.) Stroj je portabel 'ki je prenosen'; prida (prid. neskl., nav. ekspr., navadno z nikalnico): Fant ni prida.

\section{3) Nevezavni/vezavni:}

$\varnothing / \mathrm{T}_{\mathrm{ma}}$ divji / divji na (ekspr.) 'zelo jezen': Ves je divji / Nanj je ves divji;

$\varnothing / \mathrm{T}_{\mathrm{za}}$ karakterističen / karakterističen za 'ki osebo, stvar, pojav pomembno opredeljuje, določa; značilen, tipičen': Za to fazo kapitalizma je karakteristično vmešavanje države $v$ gospodarstvo;

živ (ekspr.) 'ki se zaradi velike prožnosti težko oblikuje, uredi': Po umivanju so lasje zelo živi; 
živ / živ za (ekspr.) 'ki kaže veliko nagnjenje do spolnosti': Preveč je živa, Premalo je živ zanjo;

dober (pog., s širokim pomenskim obsegom): Ta bo dober;

dober / dober za 'ki glede na kak kriterij, normo, zahtevo ustreza, koristi': biti dober / biti dober za koga/kaj/kam/za koliko časa;

\section{$\varnothing / \mathrm{M}_{\text {pri/na }}$}

lahek / lahkoten (nav. ekspr.) 'ki se duševno in telesno dobro počuti': Odšel je potolažen in lahek/lahkoten;

lahek / lahek pri (nav. ekspr.) 'ki se duševno in telesno dobro počuti': Bil je lahek, Pri plesu je bila lahka;

navzoč (z oslabljenim pomenom): Inšpektor je bil navzoč pri pouku matematike, Na sestanku so bili navzoči skoraj vsi člani;

$\varnothing / \mathrm{M}_{\mathrm{pri} / \mathrm{o} / \mathrm{v}} / \mathrm{O}_{\mathrm{z} / \mathrm{s}}$ domač / domač pri / domač z/s 'ki ne kaže strahu v občevanju z ljudmi': biti domač / biti domač pri kom / biti z njim čisto domača;

edin / edin o / edin v / edin z/s (dv. in mn.) 'ki je enakih misli, istega mnenja': Bili so (si) edini, Niso edini o tem/v tem, Edini so $\mathrm{z}$ njim.

Primeri, ki jasneje razkrivajo razlike med pridevniškostjo in povedkovniškostjo $\mathrm{v}$ istem leksemu:

- uraden (ekspr.) 'ki je zadržan': Ne bodi tako uraden; - v povedkovi rabi je pridevnik sinonimen $\mathrm{z}$ deležnikom zadržan, s prevladujočim duševno- ali telesnostanjskim pomenom, npr. Do njega je bil zadržan : V službi bo zadržan; nasproti: uradni predstavnik/naziv/postopek (izražena pomenska določnost oz. tudi oblikoslovno izražena vrstnost);

- podložen (z dajalnikom) 'podrejen': Naše dežele so bile podložne AvstroOgrski, Kmet je bil podložen graščaku; - povedkova raba sicer pridevniške iztočnice podložen izsili sinonimijo $\mathrm{z}$ deležnikom podrejen, npr. To mesto je podrejeno vladarju.

\section{Vezljivost povedkovodoločilnih (izglagolskih) pridevniških deležnikov stanja}

Vezljivost pri izglagolskih deležnikih stanja je, tako kot njihov pomen, izpeljana iz njihovih izhodiščnih glagolov, zato v primerjavi z glagolsko vezljivostjo ni posebnosti. Zanje je namreč prvotna in tipična povedkovna raba, tako da samo $\mathrm{s}$ prisojanjem stanja/lastnosti osebku ohranjajo isto vezljivost kot nezloženi povedki. Posebna skupina so povedkovodoločilni deležniki stanja iz dovršnih (zelo redko nedovršnih) neprehodnih in pretežno povratnih glagolov (osebkov udeleženec je 
hkrati povzročitelj in nositelj stanja) - zaradi dovršnosti in neprehodnosti/povratnosti izhodiščnega glagola (posledica slednjega je samo osebkov udeleženec) so pretvorbe $\mathrm{v}$ stanjskost in naprej v popridevljenje najbolj jasne. ${ }^{18}$

- Deležniki stanja so skladenjska kategorija, tipična za povedje, in izražajo lastnost stanja po dokončanem dejanju/procesu. $Z$ vmesno skladenjsko vlogo lastnostnostanjskega deležnika predstavljajo prehod med povedkovimi tvornimi deležniki in prilastkovimi popridevljenimi lastnostnimi deležniki.

- Povedkovodoločilni lastnostnostanjski deležnik nima kategorije glagolskega vida. Izguba oz. zabrisanje kategorije glagolskega vida pri deležnikih stanja (kot tudi časa in naklona kot kategorij pomenskopodstavnega povedja) je posredni dokaz, da glagolski vid za vezljivost ni relevanten.

2.1 Izglagolskost stanjskih deležnikov omogoča kar kratek vezljivostni pregled po glagolskih pomenskih skupinah (glede na stanje osebka ali na osebkovo tvorno/netvorno delovanje):

stanjski glagoli: *Ozemlje je pripadno državi (> pripadno ozemlje državi), Gozd je obsežen ( $>$ obsežen gozd), Steber je pogreznjen v zemljo, Olje je razlito naokrog;

netvorni glagoli: Te oblike so samo pojavne, Počitek je še kako želen, Zelo je čutna;

tvorni glagoli: 'omogočanja': Avto/Človek je napravljen/pripravljen, Načrti so uresničeni; 'ravnanja': Otrok je prizadeven pri hrani, Poseg je učinkovit za okolico; 'upravljanja/ustvarjanja': Vaza je postavljena v kot, Zemlja je zrahljana brez orodij, Besedilo je predelano od znanih strokovnjakov; 'govorjenja': Ljudje so seznanjeni z dogodki; 'spremembe': Teren je spremenjen zaradi poplav; 'premikanja': Naprava je premična v osi.

2.2 Možni skladenjskopomenski prehodi iz tvornega dejanja v povedkovniško stanjskost in nato v prilastek so najbolj jasno izraženi pri deležnikih na $-1 .{ }^{19} \mathrm{~V}$ okviru homonimije tvornega deležnika na -1, deležnika stanja na -1 in iz njega sprevržnega (drugotnega) lastnostnega pridevnika na -l se lahko stavčnopoložajsko in skladenjskopomensko izločijo potencialni povedkovniki na -1, vezavni ali nevezavni. Vezavnost skladenjskopomensko utrjuje in potrjuje njihovo povedkovniškost.

V Slovarju slovenskega knjižnega jezika so to geselske iztočnice s slovničnim kvalifikatorjem (prid)evnik in geselske podiztočnice v okviru glagolskih gesel.

${ }^{18}$ A. Bajec (1952: 29) ugotavlja, »da /je/ cela vrsta deležnikov na -n izgubila prvotni participialni pomen in dobila pridevniškega, dosti pa jih je v prehodnem stanju«.

${ }^{19}$ A. Bajec (1952: 48-49) za deležnike na -1 trdi, da »/se/ cela vrsta deležnikov že čuti za pridevniške ali pa so na meji med obojim pomenom«. S tem avtor posredno potrjuje povedkovniškost deležnkov na -1, npr. dorasel, izbokel, narasel obledel, odebelel, otrpel, ozebel, trhel, vrel, zamolkel ipd. 
2.2.1 Pridevniške iztočnice kot povedkovniki (prehod iz tvornosti v stanjskost še ni povsem zabrisan, hkrati pa stanjskost $\mathrm{z}$ lastnostjo omogoča smiselno popridevljanje): crkel: (pog., ekspr.) Kljuse je napol crklo 'onemoglo, zanemarjeno', nasproti: (pog.) Kljuse je crklo 'poginulo'. Podobno še: dobrodošel: Vedno je dobrodošel 'ki so ga veseli'; nedobrodošel: (ekspr.) Iz pozdrava je razbral, da ni ravno nedobrodošel 'je dobrodošel'; dorasel: (z dajalnikom) Nobeden mu v matematiki ni bil dorasel 'ki je kos čemu'; gnil: Ta jabolka so gnila 'že zgnila'; izbokel: Oči so izbokle 'izbuljene'; nabrekel: Žile so nabrekle 'ki imajo večji obseg zaradi pritiska'; nabuhel: Obraz je nabuhel 'zabuhel'; nagnil: (knjiž.) Jabolka so nagnila 'nagnita'; nakipel: (knjiž., ekspr., redko) Meso ob rani je bilo nakiplo 'nabreklo, oteklo'; nedogorel: Poleno je ostalo nedogorelo 'ki ni popolnoma zgorelo'; nedorasel: (ekspr.) Za svoja leta je precej nedorasel 'ki ni dorasel'; nedozorel: Ta človek je nedozorel 'ki ni dozorel, zrel'; neobrasel: Površina je neobrasla 'ki ni obrasla'; neodrasel: Fant je neodrasel 'ki ni odrasel'; neolesenel: Steblo je neolesenelo 'ki ni olesenelo'; neporasel: Pobočje je neporaslo 'ki ni poraslo'; neskopnel: Sneg je neskopnel 'ki še ni skopnel'; nestrohnel: Trske so nestrohnele 'ki niso strohnele'; neugasel: Ognjenik je neugasel 'ki ni ugasel'; neusahel: Cvetje je neusahlo; neuspel: Poskus je neuspel 'ki ni uspel'; nevesel: (knjiž., ekspr.) Postajal je nevesel 'ki ni vesel'; nezamrzel: Reke so nezamrzle 'ki niso zamrzle'; nezgorel: Plin je nezgorel 'ki ni zgorel'; nezrel: Ta plod/čovek je nezrel 'ki ni zrel'; novonastal: (knjiž.) Položaj je /na/novonastal 'ki je nedavno nastal, nov'; novozapadel (knjiž.) Sneg je /na/novozapadel 'ki je nedavno zapadel, nov'; obmolkel: (knjiž.) Mož je obmolkel 'ki je obmolknil'; obrasel: Hrib je obrasel z drevesi 'ki je pokrit z drevesi'; odbegel: (knjiž., ekspr.) Ta dan je odbegel 'ki je potekel, minul'; odmrzel: Zemlja je odmrzla 'ki je otajana'; odrasel: Fant je odrasel 'ki je odrastel, odraščen'; omrzel: (star.) Bil je omrzel 'ki je otrpel, premrl'; opolzel: (star.) Pot je opozla 'ki je spolz$\mathrm{ka}$, drsna'; oprhel: Slama je postala oprhla 'ki je plesniva'; osahel: Trava je osahla 'ki je usahla'; osupel: (nav. ekspr.) Bil je osupel 'ki je zelo začuden'; otrpel: (ekspr.) Bila je vsa otrpla 'ki je negiben, tog, manj občutljiv'; ovel: Šopek je ovel 'ki je nekoliko uvel'; podmolkel: (ekspr.) Ta človek je podmolkel 'ki je neodkrit, neiskren'; podrasel: Steblo je podraslo 'ki je zraslo pod čim drugim'; poginul: Žival je poginula 'ki je poginila'; poldorasel: Dekle podrasel: Drevo je poldoraslo 'ki ni popolnoma doraščen, zraščen'; polodrasel: Fant je polodrasel 'ki ni popolnoma odrasel'; polpretekel: Ta dogodek je polpretekel 'ki je razmeroma še blizu sedanjosti, sodobnosti'; polrazpadel: (knjiž.) Grad je polrazpadel 'ki je napol razpadel' nasproti: polrazpal: (knjiž.) Bajta je polrazpala 'ki je napol razpadla'; polugasel: (knjiž.) Ogenj je polugasel 'ki je skoraj ugasel'; pomrzel: Sneg je pomrzel 'ki je zmrznjen po površini'; ponikel: Voda je ponikla 'ki je poniknila'; porasel: Hrib je porasel 'ki je pokrit s čim rastočim'; potihel: (knjiž., redko) Glasovi so potihli 'ki so postali tihi, tišji'; prebegel: Vojak je prebegel 'ki je prebegnil'; predozorel: (knjiž.) Sadje je predozorelo 'ki je prezrelo'; premolkel: (knjiž.) Sogovornik je premolkel 'ki je premolknil'; prerasel: Poti so prerasle 'ki so prekrite s čim rastočim'; presahel: Studenec je presahel 'ki je navadno krajši čas brez vode'; presahel: (pren., ekspr.) Njegova vnema je presahla 'ki ni več navdušen za kaj/koga'; pribegel: (knjiž.) On je pribegel 'ki je pribežal'; primrzel: (knjiž.) Poleno je primrzlo 'ki je primrz- 
njeno'; prirasel: Goba je prirasla 'ki se je prirasla'; radoznal: (knjiž.) Otrok je radoznal 'ki je radoveden'; rasel: Njegovi zobje so dobro rasli 'ki je rastel, kot izraža določilo'; ravnorasel: (knjiž.) Les mora biti ravnorasel 'ki je ravne rasti'; razbegel: (knjiž.) čred je razbegla 'ki se je razbegla'; razmokel: (knjiž.) Tla so razmokla od dežja 'ki so razmočena'; razpokel: (knjiž.) Koža je razpokla 'ki je razpokana'; razrasel: Drevo je razraslo 'ki ima več poganjkov, vej'; sahel: (star.) Kruh je sahel 'ki je izsušen'; samonikel: Pesem/Pesnica je samonikla 'ki je izvirna, originalna'; samonikel: (knjiž.) On je samonikel 'ki je samostojen, neodvisen'; samorasel: Ta kultura je samorasla 'ki se oblikuje sama, brez pomoči in vpliva drugega'; sesahel: (knjiž.) Studenec je sesahel 'ki je usahel'; slaborasel: (redko) Otrok/Bor je slaborasel 'ki je slabo razvit, zakrnel'; stekel: Žival je stekla 'ki ima steklino'; strdel: (knjiž.) Blato je strdelo 'ki je strjeno, otrdelo'; strhel: (nar.) Les je strhel 'ki je trhel'; ubegel: (star.) Ujetnik je ubegel 'ki je pobegel'; ugasel: (knjiž.) Ljubezen je ugasla 'ki je prenehal biti, obstajati' nasproti: ugasel: (knjiž.) Pogled je ugasel 'ki ne izraža, kaže čustev, volje do udejstvovanja'; usahel: Mlaka je usahla 'ki je suha, brez vode'; nasproti: usahel: (pren. ekspr.) Delovna vnema je usahla 'ki ni več navdušen'; utihel: (knjiž.) Ljudje so utihli 'ki so postali tihi, tišji'; uvel: (ekspr.) Lepota je uvela 'ki je (v veliki meri) prenehala obstajati'; vbokel: Ploskev je vbokla 'ki ima navzdol, navznoter ukrivljeno obliko'; vrasel: (ekspr.) Pisatelj je vrasel v domačo pokrajino 'ki se vraste v kaj'; vrel: (ekspr.) Strast je vrela 'ki vre'; vseznal (knjiž.) Ta je vseznal 'ki vse zna'; vzbokel: Hrbet kamele je vzbokel 'ki ima navzgor, navzven ukrivljeno obliko'; vzbuhel (knjiž., redko) Del zemljišča je vzbuhel 'ki je izbočen, izbuhnjen'; zablodel (knjiž.) Človek je zablodel 'ki živi v nasprotju z družbenimi normami'; zabrekel: Žile so zabrekle 'ki imajo povečan obseg zaradi pritiska tekočine'; zabuhel: Bil je zabuhel od pijače 'ki ima povečan obseg navadno zaradi bolezenskega nabiranja tekočine'; zadahel: Kruh je zadahel 'ki ima zadah'; zahripel: (redko) Je zahripel 'ki je hripav'; zaletel: (knjiž.) Je zeletel 'ki je zaletav'; zamolkel: (ekspr.) Bolečina je zamolkla 'ki se ne pojavlja v izraziti obliki'; zamrkel: (knjiž.) Pogled je zamrkel 'ki je potemnel, temen'; zamrzel: Zemlja je zamrzla 'ki je prekrita z ledom'; zamrzel: (ekon.) Denar je zamrzel 'ki je neizplačjiv'; zapoznel: Razvoj je zapoznel 'ki se začne, nastopi pozneje'; zarasel: Poti so zarasle 'ki so prekrite, zapolnjene $\mathrm{z}$ rastlinjem'; zaripel: Je ves zaripel od jeze 'ki ima zaradi razburjenja rdeč in napet obraz'; zategel: Govorica je zategla 'ki ima posebno zadnje glasove daljše kot normalno'; zatohel: (redko) Moka je zatohla 'ki je zadahla'; zmrzel: Zemlja je še zmrzla 'ki je zmrznjena' nasproti: zmrzel: (ekspr.) Je preveč zmrzla 'ki jo rado pogosto zebe'; zrel: Pšenica/Deklica je že zrela 'ki v rasti, razvoju doseže stopnjo, primerno za spravilo, razmnoževanje' nasproti: zrel: Fant je zrel 'ki je telesno in duševno polno razvit' nasproti: zrel: Otrok je zrel za šolo 'ki je sposoben za kaj' nasproti: zrel: Žival je zrela za zakol 'ki je primeren za kaj' nasproti: zrel: 'ki ima ustrezne pozitivne in negativne lastnosti za kaj': Knjiga je zrela za tisk; (ekspr.) Fant je zrel za zapor, Stolp je zrel za rušenje.

2.2.2 Pridevniške podiztočnice pri glagolskih geslih kot povedkovniki (Upoštevani so popridevljeni deležniki stanja na -el samo iz dovršnih neprehodnih glagolov, primerjalno so dodani sopomenski popridevljeni deležniki stanja na -n/-t.): 
ohripel: Glas mu je ohripel; ohromel: (pren.) Njegova volja je polagoma ohromela; okamnel: Pred poveljnikom je stal kot okamnel; okorel: Sklepi so okoreli; okrepenel: Bil je kakor okrepenel od strahu; okrnel: Popki so okrneli; oledenel: Vrh/Pogled je oledenel; olesenel: Obstal je kot olesenel; omedlel: Našli so jo omedlelo; omeglel: Okna so omeglela; omesenel: Listi so omeseneli; omrtvel: Deli telesa so omrtveli; onemel: Onemel je obstal pred očetom; onemogel: Postal je onemogel, Onemogel je od dela; opustel: Gledal sem ga vsega opustelega; orumenel: Listi so orumeneli; osamel: Hiša je bila osamela, Čutil se je osamelega; osirotel: osirotel otrok; osivel: Lasje so osiveli; oslabel: Je oslabel od bolezni; oslepel: Ženska je napol oslepela; ostarel: Starši so ostareli; ostebrel: Figura je ostebrela; osteklenel/ osteklel: Pogled je osteklenel/osteklel; osupel: Bil je osupel nad njihovo neobčutljivostjo, nasproti: osupnjen: (knjiž.) Bil je osupnjen nad njihovo neobčutljivostjo; otemnel: Srebro je otemnelo od starosti; otopel: Ostali so otopeli; otrdel: Koža je otrdela; otrpel: Roke so otrple od mraza, nasproti: otrpnjen: (star.) Roke so otrpnjene od mraza; ozebel: Noge so ozeble; ozelenel: Breza je ozelenela; pordečel: Koža je pordečela; pordel: Oči so pordele; poblaznel: Človek je poblaznel; pobledel: Obraz je pobledel; počrnel: Roke so počrnele; podrasel: Gozd je podrasel, nasproti: podraščen: Gozd je zelo podraščen; pogorel: Les je pogorel; pokrnel: Ostanki kril so pokrneli; pomodrel: Ustnice so pomodrele; ponorel: Vpila je kot ponorela; pooglenel: Skorja je pooglenela; pordečel: Koža je pordečela; pordel: Večerno nebo je pordelo; porjavel: Trava je že porjavela; porumenel: Prsti so porumeneli od nikotina; posivel: Njegov obraz je bil posivel; posteklenel: Čebula je posteklenela; postvarel: Človekovo bistvo je postvarelo; posurovel: Človek je posurovel; pozelenel: Medeninasta posoda je pozelenela; preperel: Zavese na oknih so že preperele; uplahnel: Telo je uplahnelo; začrnel: Dimnik je začrnel; zagorel: Koža je zagorela od sonca; zagrenel: Moka je zagrenela; zahripel: Govornik je zahripel; zakasnel: zakasnel razvoj; zakostenel: Hrustanec je zakostenel; zakrnel: Krila so zakrnela; zaledenel: Ceste so zaledenele; zapoznel: Cvet je zapoznel; zarumenel: Skorja je zarumenela; zasedel: Noga je zasedela, nasproti: zaseden: Sedeži so zasedeni, (pog.) Ta teden je zaseden; zasopel: Preveč je zasopel, Vsa zasopela hiti dalje, nasproti: zasopen: Preveč je zasopen; zastarel: Stroj je zastarel; zatemnel: Slike so zatemnele od starosti; zbesnel: Vpije kot zbesnel; zdrevenel: (ekspr.) Ob pogledu nanj so vsi onemeli in zdreveneli; zledenel: Cesta je zledenela; zmedlel: Postal je shujšan in zmedlel.

Zgornji primeri povedkovniške rabe izločijo določene deležnike in s tem izpostavijo razmerje med slovarskim (denotativnim) in samo skladenjskim (kategorialnim) pomenom

- Pomeni nekaterim deležnikom na -l ne dopuščajo stanjske povedkovniške rabe - v povedku ohranjajo tvornost in šele v prilastkovni rabi izražajo stanjskost, npr. ponarodel: ponarodele pesmi; uspel: uspela uprizoritev; vstal: vstali otrok, vstala jeza; vzkipel: vzkipela strast; vznikel: vznikel plevel; zamrl: zamrlo življenje; zgorel: zgorela hiša/vas; znorel: znorel človek, znorela žival. zblaznel: Je zblaznel od bolečine. Iz tega tudi sledi, da imajo nekateri glagolski pomeni za izražanje stanjskosti deležnike na -n/-t, npr. predan: Muzej je predan javnosti; zadržan: Ne bo 
prišel, ker je zadržan; zbran: Pri učenju je zelo zbran; zaklet: Zaklet je v molk. Na razlikovanje tvornosti in stanjskosti v povedku kažejo tudi primeri kot oživel: Narava je oživela, nasproti: oživljen: Obraz je oživljen v pričakovanju.

- Za isti pomen se za povedkovniško in prilastkovno rabo izoblikujejo specializirane oblike, hkrati pa se pri različnih deležniških oblikah v isti skladenjski vlogi izoblikuje sinonimija kategorialnih pomenov, npr. prepadel/prepaden: Prepadli/Prepadeni so strmeli drug v drugega, nasproti: prepal: prepal človek. Možne različice so še: uvel: uvelo cvetje, nasproti: uvenel: uvenelo cvetje; zastrmel: zastrmeli ljudje, nasproti: zastrmen: zastrmeni obrazi.

Nejasno oz. prehodno razmerje med povedkovniškostjo in pridevniškostjo obravnavanih tvorjenk na -en lahko razberemo že iz Slovarja slovenskega knjižnega jezika. Razmerje med pridevniškimi iztočnicami (PI) in pridevniškimi podiztočnicami (PPI) znotraj glagolskih gesel lahko označimo kot delno popolno sinonimijo (imata vsaj en isti pomen; v celoti pa je v pomenju pridevniške iztočnice navadno poudarjena lastnost, pri še močno izglagolsko motivirani pridevniški podiztočnici oz. deležniku pa stanjskost). ${ }^{20}$ Prevladujoča stanjskost ali lastnost je posledica kategorialne pomenskosti.

Povedkovodoločilna raba s povedkovniškostjo in prilastkovna raba s popridevljenjem hkrati napovedujeta možnost desne oz. leve vezljivosti:

- z neobvezno rodilniško vezavo $\left(\mathrm{R}_{\mathrm{od}}\right)$ :

opójen (PI) - (nav. ekspr.) 'ki povzroča stanje čutnega in duševnega ugodja': Zvok njenih besed je bil opojen (> poudarjena 'lastnost');

opojèn (PPI) - (nav. ekspr.) 'stanje čutnega in duševnega ugodja': Ves opojen je od sreče (> poudarjena 'stanjskost');

- nevezavno (zato poudarjena 'stanjskost'):

osámljen (PI) - 'ki je brez družbe, brez povezave z drugimi': Zelo je osamljen in žalosten;

osámljen/osamljèn (PPI) - 'pretrgan stik, povezava z drugimi': Vsi ti bolniki so že osamljeni.

Prevladujoča povedkovodoločilna raba in z njo povedkovniškost pomenskoskladenjsko izpostavi stanjskost s posledično lastnostjo:

znàn/znán (PI) - 'ki obstaja': Afera je že splošno znana; še eno- ali dvovezavni primeri, ki iz obstajanja izpeljujejo tudi lastnost ( $>$ izraženo je z obvezno predmetno vezavo ali z neobvezno prislovnodoločilno vezavo): Ti običaji so znani na kmetih, Kraj je znan po marmorju, Znan mi je le po obrazu, Bil je znan z vsemi veljaki;

${ }^{20} \mathrm{Tu}$ se omejujem na sinonimijo v ožjem smislu oz. na leksikalno sinonimijo. Največkrat gre za delno popolno sinonimijo kot jo opredeljuje v Uvodu SSKJ (1970: XV) in jo kasneje definira še M. Zorman (2000: 68), pri J. Lyonsu (1995: 60) pa kot »partial synonymy«. 
poznàn/poznán (PI) - 'za katerega obstajanje, lastnosti se ve': Nikomur poznan človek, Ti problemi so mi poznani;

potrében $(\mathrm{PI})$ - 'ki je v stanju pomanjkanja': Za to je potreben določen čas, Potreben je denarja, Zelo mu je potreben;

pózitiven/pozitiven (PI) - 'ki obstaja in ima celo veliko vrednost': Izid preiskave je pozitiven;

pravilen (PI) - 'ki je v skladu z resničnostjo, dejstvi': Odgovor je pravilen.

Naklonskost povedkovnikov uvaja tudi vezavnost (npr. neobveznovezavni rodilnik $\left.\left(\mathrm{R}_{\mathrm{do}}\right)\right)$ :

pozóren (PI) - 'izraža skrb, zavzetost za koga': Vedno je pozorna do njega;

pravičen $(\mathrm{PI})$ - 'ki ravna $\mathrm{v}$ skladu $\mathrm{z}$ določenimi normami, načeli': Je pravičen do sosedov.

\section{Viri in literatura}

BAJEC, A., 1952, Besedotvorje slovenskega jezika. II Izpeljava slovenskih pridevnikov, III Zloženke, Ljubljana.

BREZNIK, A., 1916, Slovenska slovnica za srednje šole, 4. pomnožena izd., Celje 1934.

DAJNKO, P., 1824, Lehrbuch der Windi? chen Sprache II del: Von der Wortfügung. Gratz, 269-296.

DOBROVSKÝ, J., 1940, Podrobná mluvnice jazyka českého. (V redakcích z roku 1809 a 1819), Praha.

GREPL, M. idr., 1986, Mluvnice češtiny (2 - Tvaroslovi). Praha.

ISAČENKO, A. V., 1954, 1960, Grammatičeskij stroj russkogo jazyka v sopostavlenii s slovackim. Morfologija 1, 2. Bratislava.

KATIČIĆ, R., 1986, Sintaksa hrvatskoga književnog jezika. Zagreb.

KOZLEVČAR, I., 1969/70, O pridevniku v povedni rabi, JiS XV/1, 210-215.

LYONS, J., 1995, Linguistics semantics (An introduction), Great Britain.

METELKO, F., 1825, Lehrgebäude der Sloweni? chen Sprache im Königreiche Illyrien und in den benachbarten Provinzen, Laibach, 236-264.

Morfológia slovenského jazyka, 1966, Bratislava.

Slovar slovenskega knjižnega jezika I-V, 1970, 1975, 1979, 1985, 1991, Ljubljana. TOPORIŠIČ, J., 1982, Nova slovenska skladnja, Ljubljana.

- 2000: Slovenska slovnica, Četrta prenovljena in razširjena izdaja, Maribor.

VIDOVIČ MUHA, A., 1972, Kategorizacija in stilna opredelitev ozko knjižne leksi-

ke, VIII. seminar slovenskega jezika, literature in kulture, Ljubljana, 35-52.

- - 1978, Merila pomenske delitve nezaimenske pridevniške besede, SR XXVI/3, 255-275.

_- 1988, Slovensko skladenjsko besedotvorje ob primerih zloženk, Ljubljana.

- - 2000a, Čas v besedi (Tipologija leksikalne večpomenskosti), XXXVI. seminar slovenskega jezika, literature in kulture, Ljubljana, 85-109.

- 2000b, Slovensko leksikalno pomenoslovje, Govorica slovarja, Ljubljana. 
VINOGRADOV, V. V., 1947, Russkij jazyk (grammatičeskoe učenie o slove), Moskva, Leningrad.

ZORMAN, M., 2000, O sinonimiji, Ljubljana.

ŽELE, A., 2000, Tipologija poved(kov)ne rabe v Slovarju slovenskega knjižnega jezika, Jezikoslovni zapiski 6, 57-65.

\section{Typology of Adjectival Valency \\ Summary}

Adjectives in predicative use - both those with the original semantic spectre completely preserved, as well as those with metonymic or even metaphoric meanings - are discussed within the framework of adjectival valency. Therefore we may introduce the notion of a composite predicate and its valency.

Valency (or the syntactic-semantic perspective) can serve as one of the most important criteria for determining "predicativeness « or syntactic meanings of the predicates. The degree of syntactic-semantic fixedness in the sentence (after the copula) at the same time indicates the degree of "predicativeness « for given adjectives.

The selected set of examples from the Dictionary of Standard Slovenian (Slovar slovenskega knjižnega jezika) enables a factual presentation of the principles on which the adjectives are used in a (composite) predicate and brings a possible classification of the adjectives according to their valency: a) valency of (non-verbal) adjectives with optional valency with nonlexicalized prepositional morphemes and with obligatory valency with lexicalized prepositional morphemes, and b) valency of (verbal) adjectival participles indicating a state used as subject or object complements. 